Report of Investigation 2020-1

\title{
REGIONAL TSUNAMI HAZARD ASSESSMENT FOR COMMUNITIES OF BRISTOL BAY AND THE PRIBILOF ISLANDS, ALASKA
}

E.N. Suleimani, D.J. Nicolsky, and J.B. Salisbury

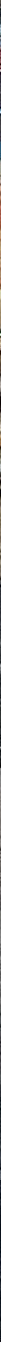


Cover. St. Paul Island, view looking north-northeast over Warehouse Street with homes in the distance. Photo: Barrett Salisbury, DGGS. 


\section{REGIONAL TSUNAMI HAZARD ASSESSMENT FOR COMMUNITIES OF BRISTOL BAY AND THE PRIBILOF ISLANDS, ALASKA}

E.N. Suleimani, D.J. Nicolsky, and J.B. Salisbury

Report of Investigation 2020-1

State of Alaska

Department of Natural Resources

Division of Geological \& Geophysical Surveys 


\section{STATE OF ALASKA}

Mike Dunleavy, Governor

\section{DEPARTMENT OF NATURAL RESOURCES}

Corri A. Feige, Commissioner

\section{DIVISION OF GEOLOGICAL \& GEOPHYSICAL SURVEYS}

Steve Masterman, State Geologist and Director

Publications produced by the Division of Geological \&

Geophysical Surveys (DGGS) are available for free download

from the DGGS website (dggs.alaska.gov). Publications on

hard-copy or digital media can be examined or purchased in

the Fairbanks office:

Alaska Division of Geological \& Geophysical Surveys

3354 College Rd., Fairbanks, Alaska 99709-3707

Phone: (907) 451-5010 Fax (907) 451-5050

dggspubs@alaska.gov|dggs.alaska.gov

\section{DGGS publications are also available at:}

Alaska State Library,

Historical Collections \& Talking Book Center

395 Whittier Street

Juneau, Alaska 99811

Alaska Resource Library and Information Services (ARLIS)

3150 C Street, Suite 100

Anchorage, Alaska 99503

\section{Suggested citation:}

Suleimani, E.N., Nicolsky, D.J., and Salisbury, J.B., 2020, Regional tsunami hazard assessment for communities of Bristol Bay and the Pribilof Islands, Alaska: Alaska Division of Geological \& Geophysical Surveys Report of Investigation 2020-1, 30

p., 6 sheets. doi.org/10.14509/30422
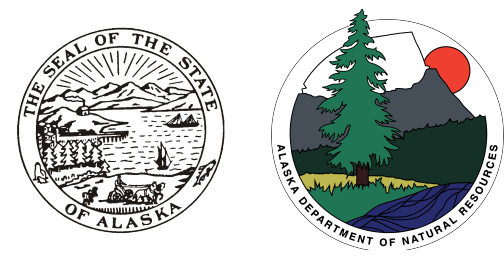


\section{Contents}

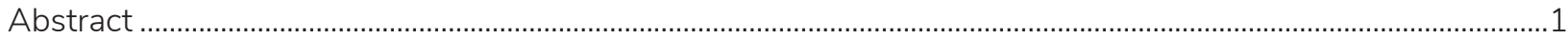

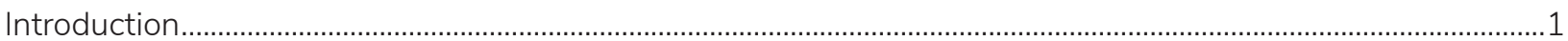

Project Background: Regional and Historical Context ...........................................................................................2

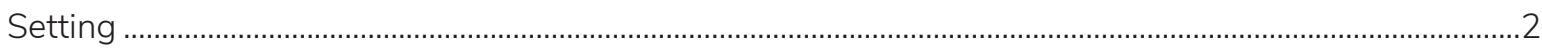

Tectonic, Volcanic, and Landslide Tsunami Hazards .....................................................................................

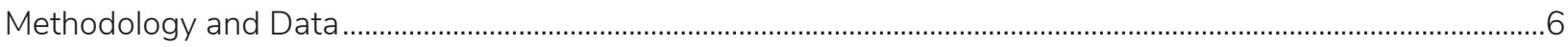

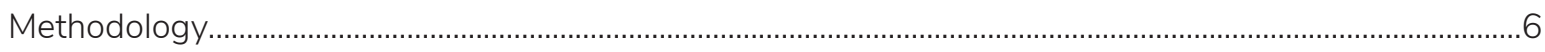

Computational Grids and Data Sources .......................................................................................................

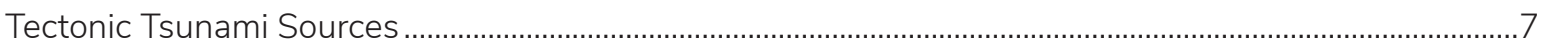

Scenario 1. $M_{W} 9.2$ earthquake: Slip at 5-45 km depth; maximum slip at $15-35 \mathrm{~km}$ depth........9

Scenario 2. $M_{W} 9.2$ earthquake: Slip at 10-50 km depth; maximum slip at 30-40 km depth.....9

Landslide Tsunami Sources....................................................................................................................... 12

Scenario 3. An underwater slide in the Bering Canyon......................................................................... 12

Scenario 4. An underwater slide on the western flank of the Umnak Plateau. ................................12

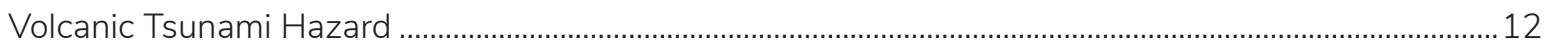

Numerical Model of Tsunami Propagation and Runup .................................................................................. 13

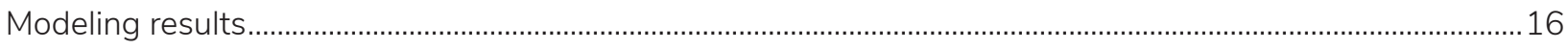

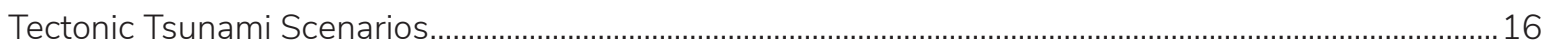

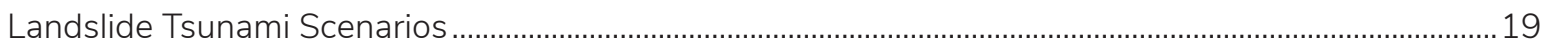

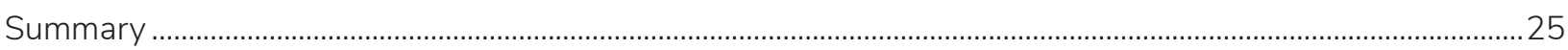

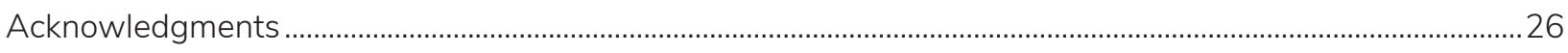

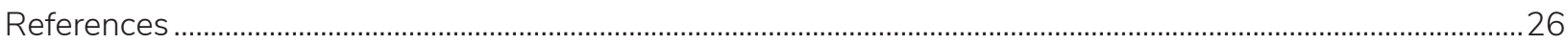

\section{Figures}

Figure 1. Map of the Bering Sea and western and south-central Alaska ..............................................................

Figure 2. Map of the eastern Bering Sea and Bristol Bay showing the locations of the five communities....... 4

Figure 3. Nested bathymetry/topography grids for numerical modeling of tsunami propagation and runup..8

Figure 4. Slip distributions and vertical coseismic deformations corresponding to scenarios 1 and 2 ..........10

Figure 5. Locations and initial landslide thicknesses for two hypothetical landslide scenarios ........................13

Figure 6. Calculated maximum tsunami amplitudes in the Bering Sea corresponding to the four

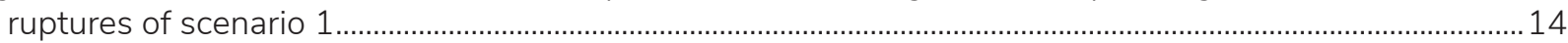

Figure 7. Maximum composite tsunami height at Dillingham ……............................................................................ 15

Figure 8. Maximum composite tsunami height at Nelson Lagoon .........................................................................16

Figure 9. Maximum composite tsunami height at Platinum ................................................................................. 17

Figure 10. Maximum composite flow depths over dry land at St. Paul calculated from all

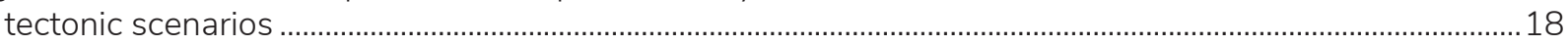

Figure 11. Maximum composite flow depths over dry land at St. George calculated from all

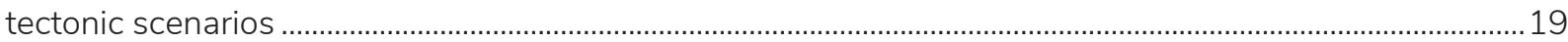

Figure 12. Maximum composite flow depths over dry land in the area of St. George airport

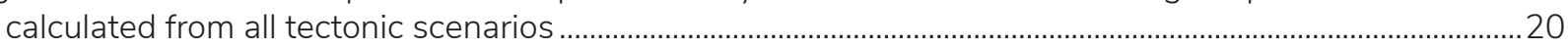

Figure 13. Time series of water level for all tectonic scenarios at the five communities ...................................21

Figure 14. Maximum wave height in the Bering Sea and Bristol Bay for landslide scenarios..........................24 


\section{Tables}

Table 1. Tsunami effects for the Bristol Bay and Pribilof Islands region ..................................................................

Table 2. Nested grids used to compute propagation of tsunami waves from nearby subduction zones to the Bristol Bay and Pribilof Islands communities

\section{Appendix}

Figure A1. Discretized model of the Alaska-Aleutian plate interface. 30

Figure A2. Slip distributions corresponding to sensitivity scenarios 1-11 .......................................................31

Table A1. Maximum tsunami heights at the St. Paul harbor for different scenarios in the sensitivity study 32

\section{Map Sheets}

Sheet 1. Tsunami hazard map of Nelson Lagoon, Alaska

Sheet 2. Tsunami hazard map of Platinum, Alaska

Sheet 3. Tsunami hazard map of Dillingham, Alaska

Sheet 4. Tsunami hazard map of St. Paul, Alaska

Sheet 5. Tsunami hazard map of St. George, Alaska

Sheet 6. Tsunami hazard map of St. George airport, Alaska 


\title{
REGIONAL TSUNAMI HAZARD ASSESSMENT FOR COMMUNITIES OF BRISTOL BAY AND THE PRIBILOF ISLANDS, ALASKA
}

\author{
E.N. Suleimani ${ }^{1}$, D.J. Nicolsky ${ }^{1}$, and J.B. Salisbury ${ }^{2}$
}

\begin{abstract}
We assess potential tsunami hazards for the communities of Dillingham, Nelson Lagoon, and Platinum in Bristol Bay, and St. Paul and St. George on the Pribilof Islands. The Bristol Bay communities have no high-resolution bathymetry or topography, therefore we conduct tsunami hazard assessments for these areas at the regional scale. The regional approach is a suitable, cost-effective approximation and replacement for high-resolution tsunami inundation maps. The Pribilof Islands communities do have the high-resolution baseline data necessary to produce high-resolution maps. The primary tsunami hazard considered for communities in this report originate from tsunamigenic earthquakes along the Alaska-Aleutian subduction zone and from underwater slope failures in the Bering Sea. Volcanic tsunamis are known to have generated waves up to $12 \mathrm{~m}$ in Bristol Bay about 3,500 years ago, but we do not model them in this study due to insufficient data on locations and volumes of these potential hazards. We numerically model tsunamis generated by eight different megathrust earthquakes and two landslide sources, analyze tsunami wave dynamics, and develop tsunami hazard maps. The tectonic tsunami scenarios that we examined simulate $M_{w} 9.2$ megathrust earthquakes with a slip distribution in the 5-35 km (3-22 mi) depth range along the Aleutian megathrust. The landslide tsunami scenarios include submarine mass failures on both sides of Umnak Plateau. The maximum assumed runup heights

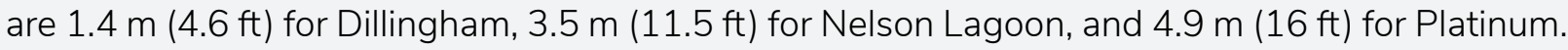

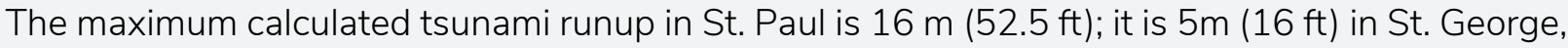

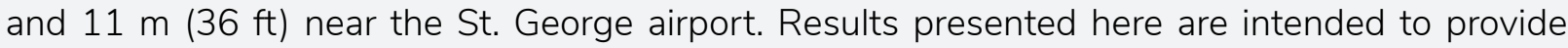
guidance to local emergency management agencies in initial tsunami inundation assessment, evacuation planning, and public education for mitigation of future tsunami hazards.
\end{abstract}

\section{INTRODUCTION}

Tsunami hazards along Alaska's Pacific coastline are widespread. Virtually all of Alaska's southern and southeastern coasts are defined by major offshore fault systems. Unlike tsunamis that are caused by distant earthquakes on the other side of the Pacific, Alaska's greatest tsunami hazards originate just offshore and can inundate coastlines within an hour of a causative earthquake. This reduces the time available to respond and evacuate and can produce drastically higher wave heights than far-traveled tsunamis. Because many Alaska communities hug the shoreline (due to some combination of steep mountains, dense forests, and/or reliance on the open water for transportation) many Alaska communities are within the tsunami inundation zone and are at risk of rapid flooding. In addition to earthquake-generated (i.e., tectonic) tsunamis, mass movements of sediments down slopes (either on land or in the ocean) can also generate tsunamis. While rapid tsunami flooding is the immediate concern after a large coastal earthquake, dangerous (potentially disastrous) nearshore ocean currents and permanent changes to the local coastline are additional concerns.

\footnotetext{
${ }^{1}$ Alaska Earthquake Center, Geophysical Institute, University of Alaska, P.O. Box 757320, Fairbanks, Alaska 99775-7320; ensuleimani@alaska.edu

${ }^{2}$ Alaska Division of Geological \& Geophysical Surveys, 3354 College Rd., Fairbanks, Alaska 99709-3707.
} 
Subduction of the Pacific plate under the North American plate has resulted in numerous great earthquakes along the Alaska-Aleutian subduction zone and has the highest potential to generate tsunamis in Alaska (Dunbar and Weaver, 2008). The Alaska-Aleutian subduction zone spans from the westernmost Aleutian Islands to the Gulf of Alaska (fig. 1). This subduction zone represents the collision between the Pacific plate to the south and the North American plate to the north. Relative to the North American plate, the Pacific Plate is moving northwest at approximately $5-8 \mathrm{~cm} \mathrm{(2-3}$ inches) per year, colliding with the North American plate and diving beneath it in a process known as subduction (Freymueller and others, 2008). The latest sequence of great earthquakes along the Alaska-Aleutian subduction zone began in 1938 with a $M_{W} 8.3$ earthquake west of Kodiak Island (Estabrook and others, 1994). Four subsequent events, the $1946 \mathrm{M}_{\mathrm{W}}$ 8.6 Aleutian (Lopez and Okal, 2006), the $1957 \mathrm{M}_{\mathrm{W}}$ 8.6 Andreanof Islands (Johnson and others, 1994), the $1964 \mathrm{M}_{\mathrm{W}} 9.2$ Alaska (Kanamori, 1970), and the $1965 \mathrm{M}_{\mathrm{W}} 8.7$ Rat Island (Wu and Kanamori, 1973) earthquakes, ruptured almost the entire length of the megathrust. Tsunamis generated by these great earthquakes reached Alaska coastal communities within minutes after the earthquakes and resulted in widespread damage and loss of life (National Centers for Environmental Information [NCEI; formerly known as National Geophysical Data Center] Global Historical Tsunami Database, doi.org/10.7289/V5PN93H7).

The impacts of future earthquakes and tsunamis can be reduced if citizens, emergency managers, and city planners take steps to mitigate the hazards. This report is intended to support hazard mitigation efforts by providing tsunami hazard estimates for the communities of Dillingham, Nelson Lagoon, and Platinum in Bristol Bay, and St. Paul and St. George on the Pribilof Islands. The maps, documentation, and available digital data provide a foundation for public education, support the development of evacuation procedures, and provide insights intended to improve community resilience.

\section{PROJECT BACKGROUND: REGIONAL AND HISTORICAL CONTEXT}

\section{Setting}

The waters of Bristol Bay line the northwestern shores of the Alaska Peninsula to the shores of Togiak National Wildlife Refuge in western Alaska, forming the easternmost inlet of the Bering Sea (figs. 1 and 2). The entire bay sits on the Bering Sea shelf, which forms the continental margin of western Alaska that extends as far south as Unimak Island and as far west as the Chukotka Peninsula of the Russian Far East. The edge of the Bering Sea shelf can be clearly seen in the bathymetry as a line of steep cliffs stretching northwest across the Bering Sea (fig. 1). The Bering Sea freezes during winter, and arctic sea ice often extends to the southern tip of the Alaska Peninsula between February and March, freezing the entire Bristol Bay from northern to southern shore (Zador and Sitten, 2016).

Over 4,000 people live along the coastline of Bristol Bay, scattered across small, mostly Native Alaskan communities (DCCED/DCRA, 2013). The region's hub is Dillingham, with a population of 2,316 (fig. 2). Dillingham supports a variety of critical infrastructure, including a hospital and three schools. There is a city-owned tidal harbor that is operated seasonally and serviced by two barge lines from Seattle. The state-owned airport has a paved runway that supports regular jet flights from Anchorage, and there is a seaplane base owned by the U.S. Bureau of Land Management. The smaller communities around Bristol Bay vary in population from less than 50 to several hundred residents. They are accessed by boat or plane because very few roads exist outside of these smaller population centers. Bristol Bay supports the largest sockeye salmon fishery in the world, and fishing-both commercial and subsistence-forms the backbone of the economy of the region. The fishing industry employs 8,000 seasonal workers in the area, and is thought to contribute over $\$ 1$ billion in value to 


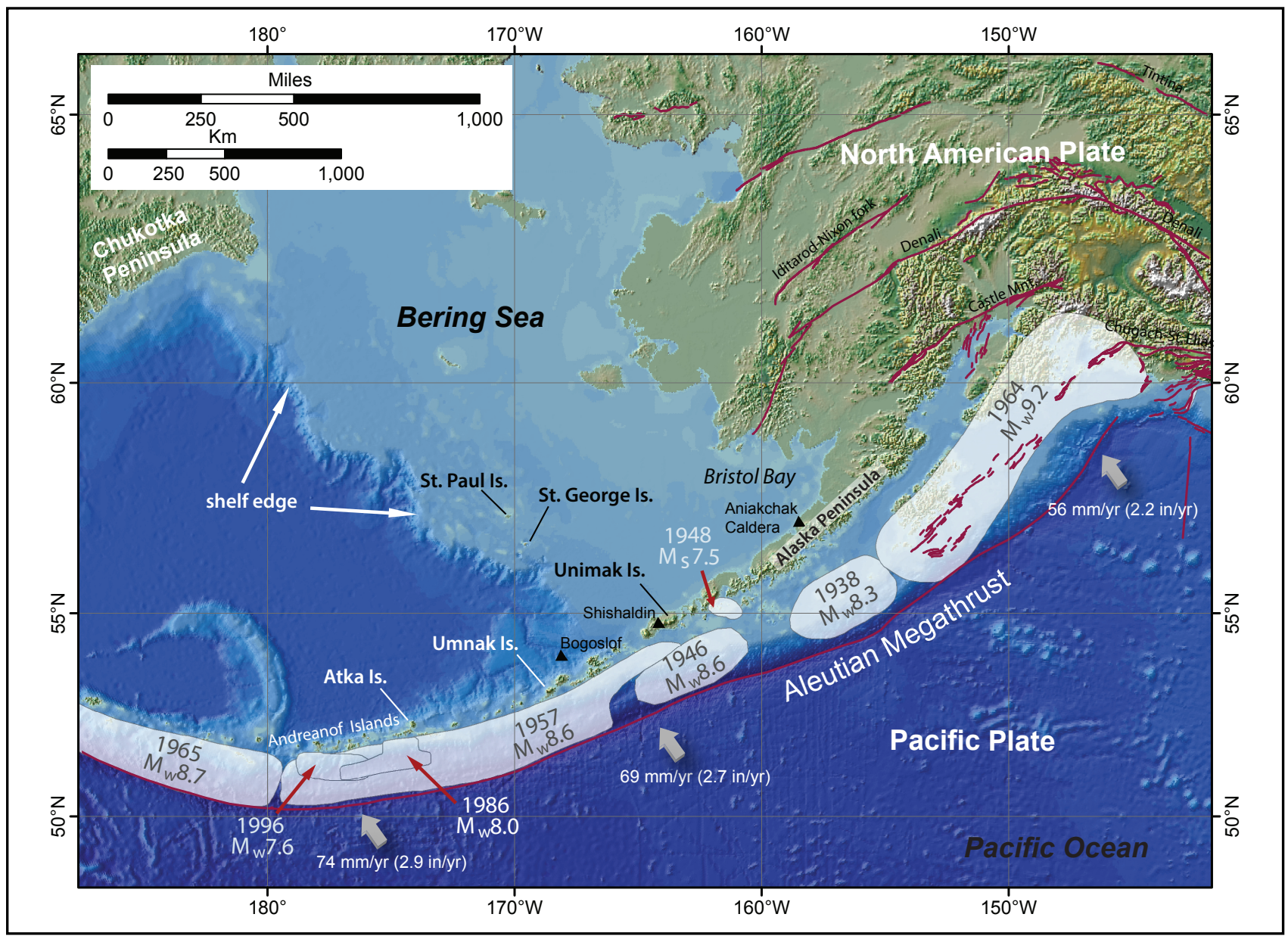

Figure 1. Map of the Bering Sea and western and south-central Alaska identifying major active or potentially active faults (dark purple lines) and the rupture zones of the 1938, 1946, 1948, 1957, 1964, and 1965 earthquakes (light shaded areas). Black triangles are active volcanoes referred to in the text.

the United States economy every year (Knapp and others, 2013).

The Pribilof Islands, a small group of volcanic islands located west of Bristol Bay in the Bering Sea, are located about 200 miles $(322 \mathrm{~km})$ northwest of Unalaska and 170 miles $(274 \mathrm{~km})$ west-southwest of Dillingham (figs. 1 and 2). Small Native Alaskan communities exist on St Paul Island (population 397) and St George Island (population 72), which are separated by 47 miles $(76 \mathrm{~km}$ ) of open ocean. Both communities have airports and harbors, and both rely on barges for the shipment of freight and non-perishable foods (DCCED/DCRA, 2013). Although originally fur-trading communities, the villages are now developing commercial fisheries and a local tourism industry.

\section{Tectonic, Volcanic, and Landslide Tsunami Hazards}

Very little was previously known about the tsunami hazards around Bristol Bay. Although they are rare, reports of tsunami inundation do exist for scattered locations around the Bering Sea. Newspaper reports from the coast near Nome, for example, tell of a tsunami destroying property and washing away buildings on November 5 , 1910. With the weather calm and no earthquakes reported, the waves were speculated to have been generated by volcanic activity from either Bogoslof or Shishaldin volcanoes in the central Aleutians (fig. 1), both of which were known to have been erupting (Sydney Morning Herald, 1910). 


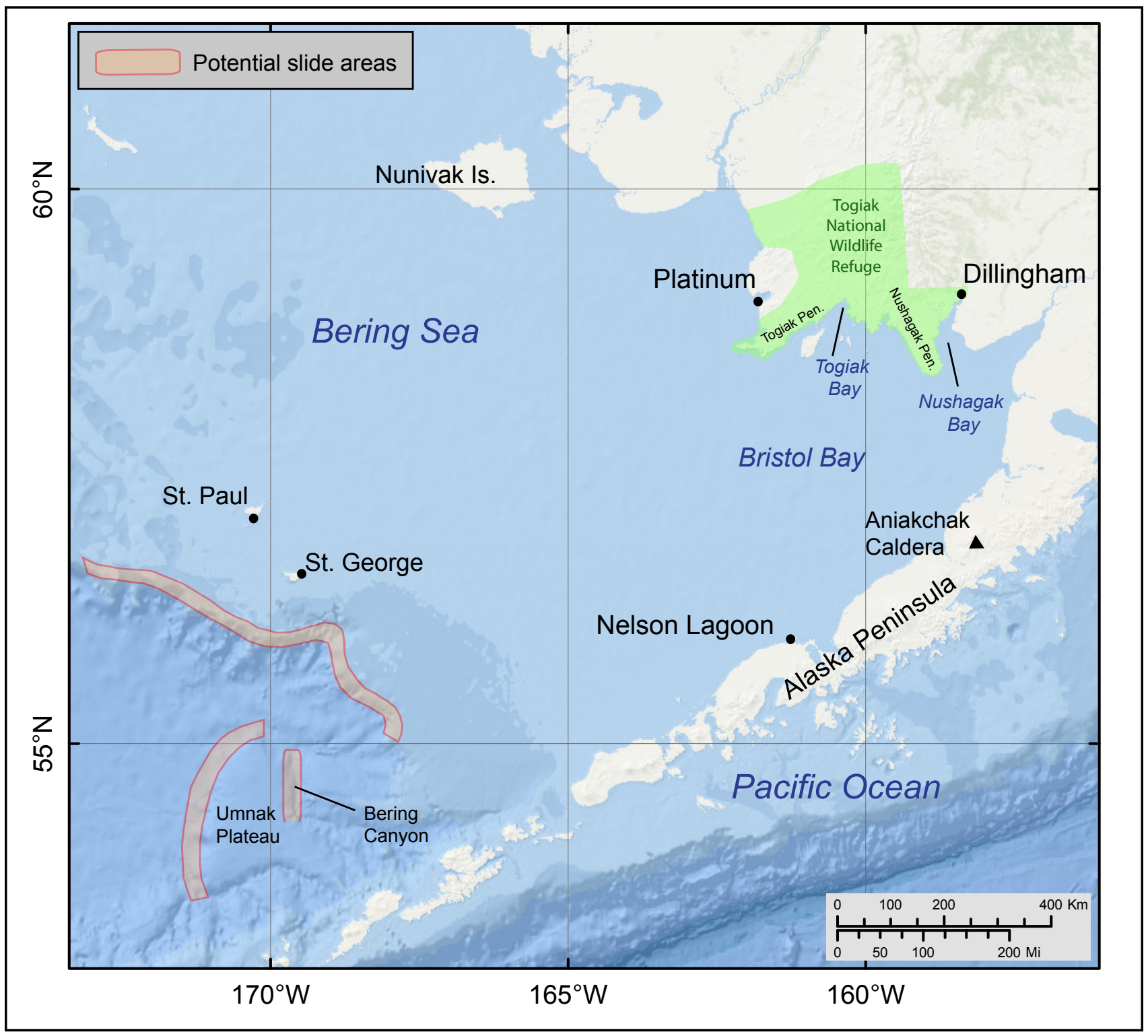

Figure 2. Map of the eastern Bering Sea and Bristol Bay showing the locations of the five communities in the current study. The areas of potential underwater slides are shaded in pink.

Bristol Bay is isolated from the Pacific Ocean by the Alaska Peninsula, which protects it from tsunamis generated elsewhere in the Pacific Ocean. Even though historic records indicate that none of the historic great earthquakes along the Aleutian megathrust generated tsunamis that reached Bristol Bay, these records are very limited and cannot be used to conclude an absence of tsunami hazard in the area. Earthquake-generated tsunamis are generally thought to be unlikely to occur in the Bristol Bay region because there are no young, high- angle fault systems to produce seafloor displacement needed to generate a tsunami (Waythomas and Neal, 1998). According to the NCEI Global Historical Tsunami Database and Lander (1996), on August 23, 1872, there was a trans-Pacific tsunami recorded in Astoria, San Francisco, San Diego, and Honolulu (table 1). The source of this tsunami was unknown until recently, when Lander found a marigram from St. Paul Island that recorded the 1872 tsunami and confirmed the source area near the Fox Islands, as proposed by 
Table 1. Tsunami effects for the Bristol Bay and Pribilof Islands region. Data from the National Centers for Environmental Information (NCEl; formerly known as National Geophysical Data Center [NGDC]) Global Historical Tsunami Database (doi.org/10/7289/V5PN93H7) and comments from Lander (1996).

\begin{tabular}{|c|c|c|c|l|}
\hline Date & $\begin{array}{c}\text { Magnitude } \\
\left(\mathbf{M}_{\mathbf{w}}\right)\end{array}$ & Origin & $\begin{array}{c}\text { Maximum } \\
\text { runup height } \\
(\mathbf{m})\end{array}$ & \multicolumn{1}{c|}{ Comments } \\
\hline 3,430 B.C.E. & n/a & $\begin{array}{c}\text { Aniakchak } \\
\text { Caldera }\end{array}$ & 12 & $\begin{array}{l}\text { Volcanogenic source, deposits recorded in } \\
\text { Nushagak Bay, around Nushagak Peninsula, } \\
\text { and in Togiak Bay. The maximum runup } \\
\text { height was inferred from the elevation of the } \\
\text { tsunami deposit. }\end{array}$ \\
\hline 08/23/1872 & Unknown & Fox Islands & Unknown & $\begin{array}{l}\text { Recorded at Village Cove on St. Paul Island. } \\
\text { Period 33 to 34 minutes, maximum water } \\
\text { height 0.75 feet. }\end{array}$ \\
\hline
\end{tabular}

Cox (1984). This marigram is the earliest record of an Alaska tsunami, and the 1872 earthquake in the Fox Islands was the first instrumentally-located tsunami source in the world (Lander, 1996).

Landslides also pose a tsunami threat to the Bristol Bay coastline. The sudden movement of a large volume of material (i.e., an underwater slope failure) can generate a tsunami, even if the failure occurs well below the water surface. Massive landslides along continental slopes have caused great tsunamis in the past. The Storegga Slide (Bryn and others, 2005) and the Grand Banks Slide (Fine and others, 2005) generated catastrophic tsunamis along the Norway and Canada coastlines, respectively. Underwater landslides tend to happen in areas where thick bodies of unstable sediment have accumulated on steep underwater slopes (Lee and others, 2006). In the Bristol Bay region, these conditions are met along the actively-eroding edge of the Bering Sea shelf (fig. 2).

Bathymetric and seismic-reflection surveys of the Beringian margin have revealed several major underwater canyon systems that show evidence of past landslides (Cooper and others, 1986; Carlson and others, 1991). For example, mass movement along the southern part of the margin is widespread at the edges of the Umnak Plateau (fig. 2).
The unstable sediment deposited at the Bering Sea shelf break can be triggered by earthquake-induced shaking. Large subduction zone earthquakes along the Aleutian megathrust as well as crustal earthquakes occurring in the Bering Sea shelf can trigger mass failures along this extensively eroded margin. Carlson and others (1991) also suggest that wave loading from violent winter storms could be another likely landslide-triggering mechanism.

Volcanic eruptions also have the potential to generate tsunamis in Bristol Bay. Volcanogenic tsunamis occur when rock material from an edifice collapse, debris avalanche, or large-volume pyroclastic flow from a volcano suddenly enters water, generating large waves that can travel quickly for long distances. Volcanic rocks found within tsunami deposits along the shores of Nushagak Bay, the Nushagak Peninsula, and Togiak Bay show that this has happened on at least one past occasion in Bristol Bay (fig. 2; Allen, 1994; Lea, 1989). Studies of these deposits indicate that they were formed 3,430 years ago during a catastrophic eruption of Aniakchak Caldera, located more than 120 miles $(193 \mathrm{~km})$ away on the Alaska Peninsula (table 1). This eruption sent a large, fast-moving flow of hot volcanic rock into the waters of Bristol Bay, generating a tsunami with run-ups as high as 
$12 \mathrm{~m}$ (40 ft) in Nushagak Bay (Lea, 1989; Allen, 1994; Waythomas and others, 1995; Armes, 1996; Waythomas and Neal, 1998; Waythomas and Watts, 2003). With several active volcanic centers located along the southern shore of Bristol Bay, there exists the potential for similar future volcanic tsunamis in the region.

\section{METHODOLOGY AND DATA Methodology}

In recent years, similar tsunami hazard studies have been published for Adak, Atka, False Pass, Perryville, Shemya, and several other coastal communities. Because the currently available elevation data for Dillingham, Nelson Lagoon, and Platinum are of insufficient quality for high-resolution modeling, we follow the National Tsunami Hazard Mitigation Program (NTHMP, 2010) guidelines (nws.weather.gov/nthmp/publications.html) for determining tsunami hazard zones for areas that have either low risk due to small population size and minimal infrastructure vulnerability, or do not have access to high-resolution topographic or bathymetric data. The tsunami hazard maps of Dillingham, Nelson Lagoon, and Platinum are developed using the methodology described in detail in Suleimani and others (2018). In short, for the four earthquake and landslide scenarios, we modeled water dynamics from source to community and computed maximum tsunami wave heights using the highest-resolution grids available (table 2). For the communities of St. Paul and St. George, we performed numerical modeling of tsunami waves using high-resolution digital elevation models (DEMs) of combined bathymetry and topography, which have been verified with local RTK GPS surveys. For these two communities, we simulated the potential inundation with the best available high-resolution data with a spatial resolution of 15 $\mathrm{m}$ (49 ft), and developed high-resolution tsunami inundation maps with methodology described in Suleimani and others (2015). Each model run covers 12 hours of post-earthquake tsunami propagation to account for all waves in the wave train, as well as secondary (reflected) wave interactions. At every location throughout the high-resolution grids, the maximum tsunami height from any of the four earthquakes is saved, and we use these maximum values to generate a new, "composite" map of maximum wave heights that can be expected from the earthquake scenarios.

\section{Computational Grids and Data Sources}

We model tsunami waves and inundation using a series of nested computational grids. A nested grid allows for higher resolution computations in areas where detail is needed while minimizing computer runtime in areas where such detail is not required. The bathymetric and topographic relief in each nested grid is based on DEMs developed at the NCEI. The extent of each grid used for the Bristol Bay and Pribilof Islands mapping project is shown in figure 3 and listed in table 2 . The coarsest grid (level 0 ), with 2-arc-minute (approximately $2 \mathrm{~km}$ ) resolution, spans the central and northern Pacific Ocean. The bathymetric data for the 2-arc-minute-resolution grid is extracted from the ETOPO2 dataset (NGDC, 2006, doi.org/10.7289/V5J1012Q). We use two intermediate grids between the coarsest- and highest-resolution grids (table 2). The data sources and methodology used to develop the 24-arc-second DEMs are described in detail by Lim and others (2011). The 8- and 8/3-arc-second DEMs were developed by the NCEI in the scope of NTHMP (Jason Caldwell, written commun.).

The spatial resolution of the fine resolution grid cells, which is $-48 \times 82 \mathrm{~m}(157 \times 269 \mathrm{ft})$, satisfies NOAA's minimum recommended requirements for estimation of the tsunami hazard zone (NTHMP, 2010). We stress that this grid spacing is not adequate for the high-resolution modeling of the inundation zone and no DEM verification efforts were conducted to reduce uncertainties in the fine resolution grids for Dillingham, Nelson Lagoon, and Platinum. Therefore, in this report we perform high-resolution runup modeling only for the communities of St. Paul and St. George. For the communities 
of Dillingham, Nelson Lagoon, and Platinum we provide an estimation of the tsunami hazard zone by extrapolating the maximum composite tsunami wave height onto land according to the tsunami scenarios described below. We account for uncertainties inherent to this method by applying a 30 percent safety factor to the estimated hazard zone.

\section{Tectonic Tsunami Sources}

We use a deterministic approach for our earthquake and tsunami hazard modeling. We define the largest hypothetical, yet scientifically-defendable earthquake scenarios that could affect the commu- nities and calculate the potential resulting tsunami inundation. Although we do not explicitly develop the "worst-case" scenarios for each community, we develop our earthquake sources based on previous studies focused on maximum credible scenarios for coastal Alaska. This approach is drastically different from probabilistic hazard analyses used for land-use planning or insurance estimates (Geist and Parsons, 2006). Probabilistic earthquake hazards consider all possible earthquakes (both large and small) and define the probability that an earthquake of a certain magnitude will occur in a given amount of time.

Table 2. Nested grids used to compute propagation of tsunami waves from nearby subduction zones to the Bristol Bay and Pribilof Islands communities. The fine- and high-resolution grids are used to compute the inundation in Bristol Bay and the Pribilof Islands, respectively. Note that the grid resolution in meters is not uniform: the first dimension is the longitudinal grid resolution and the second is the latitudinal resolution. Measurements also vary across each grid and are given for a reference location near Dillingham to illustrate relative grid fineness.

\begin{tabular}{|c|c|c|c|c|}
\hline \multirow[b]{2}{*}{ Grid name } & \multicolumn{2}{|c|}{ Resolution } & \multirow[b]{2}{*}{ East-West boundaries } & \multirow[b]{2}{*}{ North-South boundaries } \\
\hline & $\begin{array}{l}\text { Arc- } \\
\text { seconds }\end{array}$ & $\begin{array}{l}\text { Meters (near } \\
\text { Dillingham) }\end{array}$ & & \\
\hline Level 0, Northern Pacific & $120 \times 120$ & $\approx 1,909 \times 3,704$ & $120^{\circ} 00^{\prime} \mathrm{E}-100^{\circ} 00^{\prime} \mathrm{W}$ & $10^{\circ} 00^{\prime} \mathrm{N}-65^{\circ} 00^{\prime} \mathrm{N}$ \\
\hline Level 1, Bristol Bay & $24 \times 24$ & $\approx 382 \times 741$ & $176^{\circ} 24^{\prime} 48^{\prime \prime} \mathrm{W}-157^{\circ} 11^{\prime} 12^{\prime \prime} \mathrm{W}$ & $51^{\circ} 30^{\prime} 12^{\prime \prime} N-61^{\circ} 01^{\prime} 48^{\prime \prime} N$ \\
\hline $\begin{array}{l}\text { Level 2, Coarse } \\
\text { resolution, Dillingham }\end{array}$ & $8 \times 8$ & $\approx 127 \times 247$ & $160^{\circ} 52^{\prime} 08^{\prime \prime} \mathrm{W}-157^{\circ} 41^{\prime} 52^{\prime \prime} \mathrm{W}$ & $56^{\circ} 25^{\prime} 16^{\prime \prime} \mathrm{N}-59^{\circ} 13^{\prime} 32^{\prime \prime} \mathrm{N}$ \\
\hline $\begin{array}{l}\text { Level 2, Coarse } \\
\text { resolution, Nelson Lagoon }\end{array}$ & $8 \times 8$ & $\approx 127 \times 247$ & $164^{\circ} 56^{\prime} 08^{\prime \prime} \mathrm{W}-161^{\circ} 14^{\prime} 16^{\prime \prime} \mathrm{W}$ & $54^{\circ} 59^{\prime} 40^{\prime \prime} \mathrm{N}-56^{\circ} 24^{\prime} 20^{\prime \prime} \mathrm{N}$ \\
\hline $\begin{array}{l}\text { Level } 2 \text {, Coarse } \\
\text { resolution, Platinum }\end{array}$ & $8 \times 8$ & $\approx 127 \times 247$ & $163^{\circ} 52^{\prime} 08^{\prime \prime} \mathrm{W}-161^{\circ} 04^{\prime} 16^{\prime \prime} \mathrm{W}$ & $58^{\circ} 05^{\prime} 40^{\prime \prime} \mathrm{N}-60^{\circ} 49^{\prime} 08^{\prime \prime} \mathrm{N}$ \\
\hline $\begin{array}{l}\text { Level } 2 \text {, Coarse } \\
\text { resolution, Pribilof Islands }\end{array}$ & $8 \times 8$ & $\approx 127 \times 247$ & $172^{\circ} 55^{\prime} 20^{\prime \prime} \mathrm{W}-168^{\circ} 48^{\prime} 16^{\prime \prime} \mathrm{W}$ & $55^{\circ} 26^{\prime} 28^{\prime \prime} N-57^{\circ} 25^{\prime} 56^{\prime \prime} N$ \\
\hline $\begin{array}{l}\text { Level 3, Fine resolution, } \\
\text { Dillingham }\end{array}$ & $3 \times 3$ & $\approx 42 \times 82$ & $159^{\circ} 57^{\prime} 23^{\prime \prime} W-158^{\circ} 58^{\prime} 45^{\prime \prime} W$ & $58^{\circ} 32^{\prime} 09^{\prime \prime} N-59^{\circ} 06^{\prime} 23^{\prime \prime} N$ \\
\hline $\begin{array}{l}\text { Level 3, Fine resolution, } \\
\text { Nelson Lagoon }\end{array}$ & $3 \times 3$ & $\approx 42 \times 82$ & $162^{\circ} 41^{\prime} 23^{\prime \prime} W-161^{\circ} 44^{\prime} 45^{\prime \prime} W$ & $55^{\circ} 53^{\prime} 29^{\prime \prime} \mathrm{N}-56^{\circ} 06^{\prime} 31^{\prime \prime} \mathrm{N}$ \\
\hline $\begin{array}{l}\text { Level 3, Fine resolution, } \\
\text { Platinum }\end{array}$ & $3 \times 3$ & $\approx 42 \times 82$ & $163^{\circ} 19^{\prime} 31^{\prime \prime} \mathrm{W}-162^{\circ} 21^{\prime} 17^{\prime \prime} \mathrm{W}$ & $58^{\circ} 50^{\prime} 17^{\prime \prime} N-59^{\circ} 16^{\prime} 47^{\prime \prime} N$ \\
\hline $\begin{array}{l}\text { Level 3, Fine resolution, } \\
\text { Pribilof Islands }\end{array}$ & $3 \times 3$ & $\approx 42 \times 82$ & $171^{\circ} 47^{\prime} 31^{\prime \prime} \mathrm{W}-170^{\circ} 21^{\prime} 35^{\prime \prime} \mathrm{W}$ & $56^{\circ} 22^{\prime} 49^{\prime \prime} N-57^{\circ} 21^{\prime} 35^{\prime \prime} N$ \\
\hline $\begin{array}{l}\text { Level } 4 \text {, High resolution, } \\
\text { St. George }\end{array}$ & $8 / 9 \times 1 / 2$ & $\approx 13 \times 16$ & $170^{\circ} 36^{\prime} 59^{\prime \prime} \mathrm{W}-170^{\circ} 30^{\prime} 15^{\prime \prime} \mathrm{W}$ & $56^{\circ} 35^{\prime} 47^{\prime \prime} N-56^{\circ} 37^{\prime} 14^{\prime \prime} N$ \\
\hline $\begin{array}{l}\text { Level } 4 \text {, High resolution, } \\
\text { St. George airport }\end{array}$ & $8 / 9 \times 1 / 2$ & $\approx 11 \times 16$ & $170^{\circ} 43^{\prime} 05^{\prime \prime} \mathrm{W}-170^{\circ} 39^{\prime} 14^{\prime \prime} \mathrm{W}$ & $56^{\circ} 33^{\prime} 15^{\prime \prime} N-56^{\circ} 35^{\prime} 20^{\prime \prime} N$ \\
\hline $\begin{array}{l}\text { Level } 4 \text {, High resolution, } \\
\text { St. Paul }\end{array}$ & $8 / 9 \times 1 / 2$ & $\approx 12 \times 16$ & $171^{\circ} 20^{\prime} 20^{\prime \prime} \mathrm{W}-171^{\circ} 12^{\prime} 23^{\prime \prime} \mathrm{W}$ & $57^{\circ} 05^{\prime} 28^{\prime \prime} N-57^{\circ} 10^{\prime} 53^{\prime \prime} N$ \\
\hline
\end{tabular}




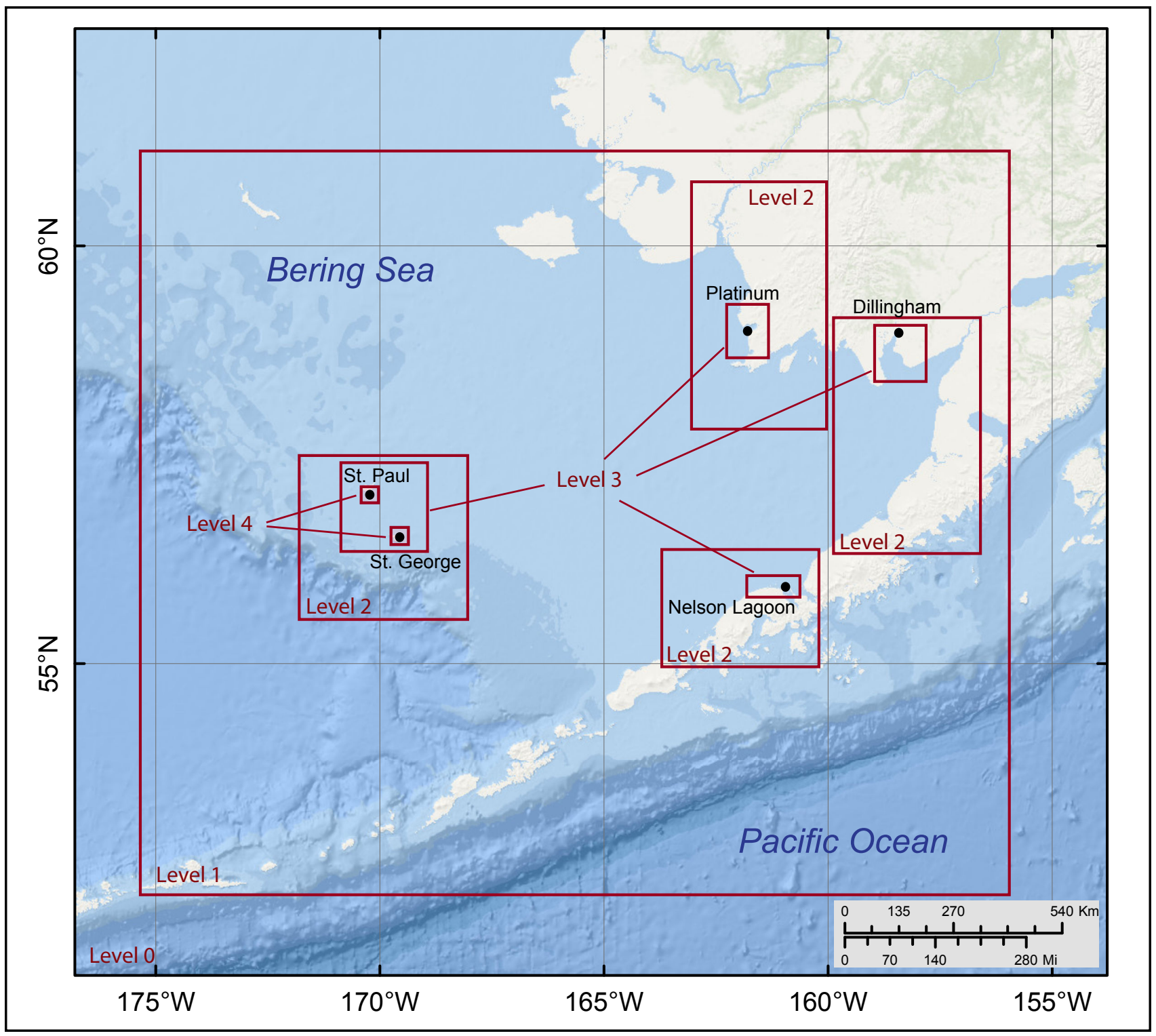

Figure 3. Nested bathymetry/topography grids for numerical modeling of tsunami propagation and runup. The coarsest grid, level 0, covers the central and northern Pacific Ocean. The location of each embedded grid is marked by a red rectangle. Refer to table 2 for grid parameters.

For this project, we consider several characteristic tsunami scenarios that in previous numerical simulations produced potentially devastating waves at other coastal communities located on the Pacific side of the Alaska Peninsula and the Aleutian arc (Nicolsky and others, 2015; Suleimani and others, 2016). These potential ruptures, with a uniform slip distribution along strike, are positioned on the Alaska-Aleutian subduction interface south of the Alaska Peninsula and Aleutian Islands. The goal is to place the potential tsunami sources in such a way that the resulting waves propagate through every opening between the islands, and therefore maximize the amount of tsunami energy that can penetrate into the Bering Sea. The proposed tsunami sources differ in the downdip slip distribution pattern, which means that the depth range at which the maximum slip occurs varies from the shallow region to the deeper parts of the plate interface. In addition, we conducted a sensitivity study to determine which rupture location along the Aleutian arc results in the highest tsunami amplitudes at the St. Paul harbor (Appendix A). 
We construct the scenarios using the following procedure:

1. To simulate potential tsunami sources on the Alaska-Aleutian megathrust, we employ a discretized model (Nicolsky and others, 2015) of the Alaska-Aleutian plate interface (Hayes and others, 2012) between the subducting and overriding plates, a section of which is shown in figure A1. To each rectangle of the plate interface, we prescribe a particular amount of slip, and the sum of all rectangles results in the total slip distribution. To define coseismic slip of hypothetical ruptures in the downdip direction, we use either a previously considered slip distribution or parameterize it by formulas according to Freund and Barnett (1976).

2. All ruptures have the same extent and a uniform slip distribution along strike. We place the first $800-\mathrm{km}$ long hypothetical rupture with its eastern end coinciding with the end of the Alaska Peninsula. Three similar ruptures are successively placed along the megathrust, each of them shifted in the along-strike direction about $200 \mathrm{~km}$ to the west with respect to the previous one (figs. 4).

3. The first four ruptures have slip distributed between depths of 5 and $45 \mathrm{~km}$ ( 3 and 15 miles) of the plate interface, with the maximum slip of $35 \mathrm{~m}$ (115 ft) located between depths of 15 and $35 \mathrm{~km}$ (9 and 22 miles) (fig. 4). The second four ruptures have the same extents in the along-strike direction, and have slip distributed between depths of 10 and $50 \mathrm{~km}$ ( 6 and 31 miles) of the plate interface, with the maximum slip of $35 \mathrm{~m}(115 \mathrm{ft})$ located between the depths of 30 and $40 \mathrm{~km}$ (19 and 25 miles) (fig. 4). The assumed maximum slip of $35 \mathrm{~m}(115 \mathrm{ft})$ is consistent with other modeling studies (such as Butler, 2014) for this region.

Below we describe the significant credible tectonic tsunami sources for the communities of Bristol Bay and the Pribilof Islands. The proposed slip distributions and vertical coseismic deformations for these scenarios are shown in figure 4 .
Scenario 1. $M_{W} 9.2$ earthquake: Slip at 5-45 km depth; maximum slip at 15-35 km depth.

Scenario 2. $M_{w} 9.2$ earthquake: Slip at 10-50 $\mathrm{km}$ depth; maximum slip at 30-40 km depth.
This event is a hypothetical $M_{W} 9.2$ earthquake rupturing the Alaska-Aleutian megathrust. The slip is distributed uniformly along strike. The maximum slip of $35 \mathrm{~m}(115 \mathrm{ft})$ is at a depth of 15-35 km (9-22 mi). For this scenario, we consider four ruptures (A-D) with the same slip distribution that are offset about 200 $\mathrm{km}$ along the direction of the megathrust.

This event is a hypothetical $M_{w} 9.2$ earthquake rupturing the Alaska-Aleutian megathrust. The slip is distributed almost uniformly along strike except for the edges of the rupture, where it tapers. The maximum slip of $35 \mathrm{~m}(115 \mathrm{ft})$ is at a depth of $30-40$ $\mathrm{km}$ (18-25 mi). For this scenario, we consider four ruptures $(\mathrm{E}-\mathrm{H})$ with the same slip distribution that are offset about 200 $\mathrm{km}$ along the direction of the megathrust. 
Scenario 1: $M_{W} 9.2$ earthquake with maximum slip at $15-35 \mathrm{~km}$ depth.
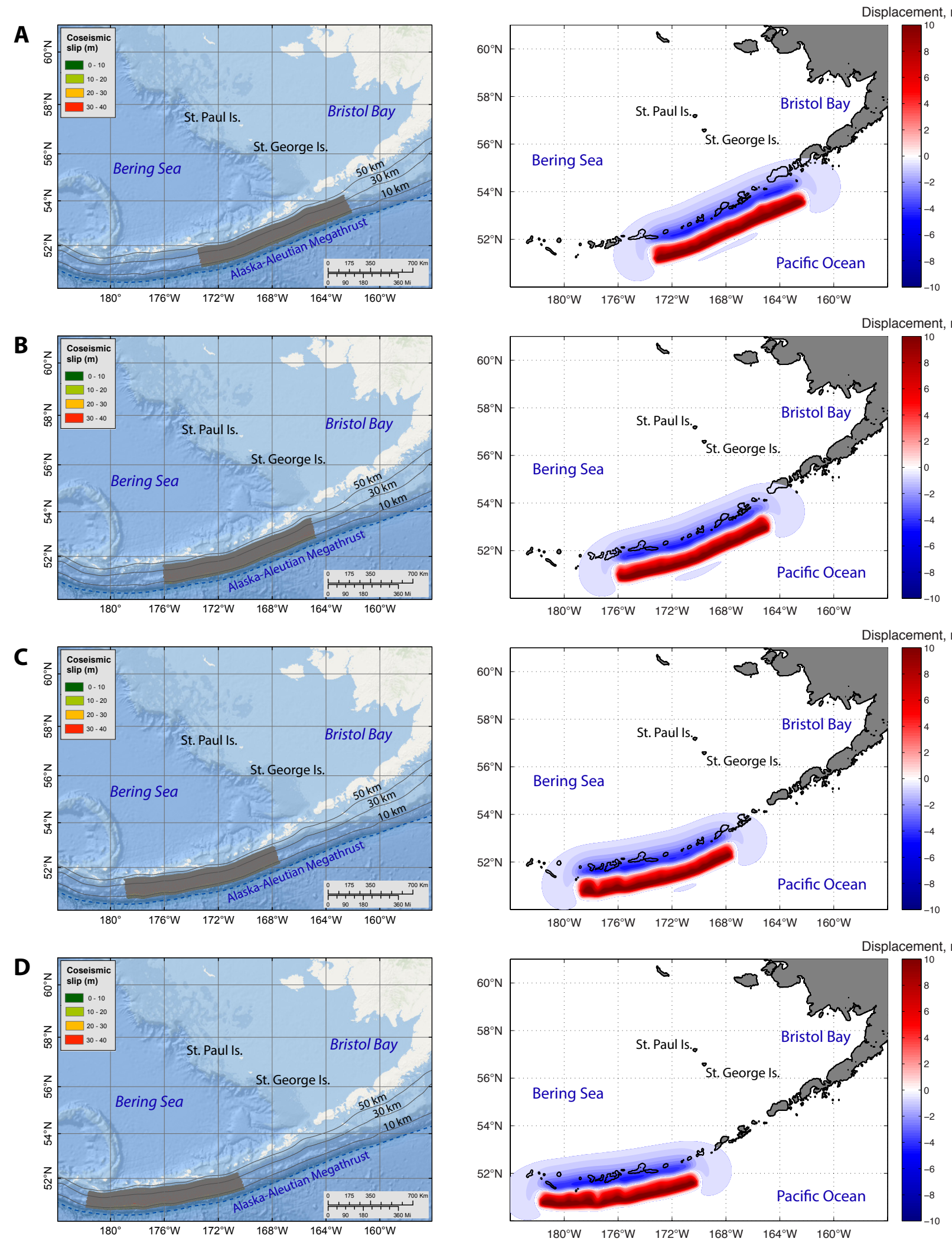

Figure 4A. Slip distributions (left column) and vertical coseismic deformations (right column) corresponding to scenarios 1. Blue areas are associated with regional coseismic ground subsidence; areas of uplift are shown in red. 


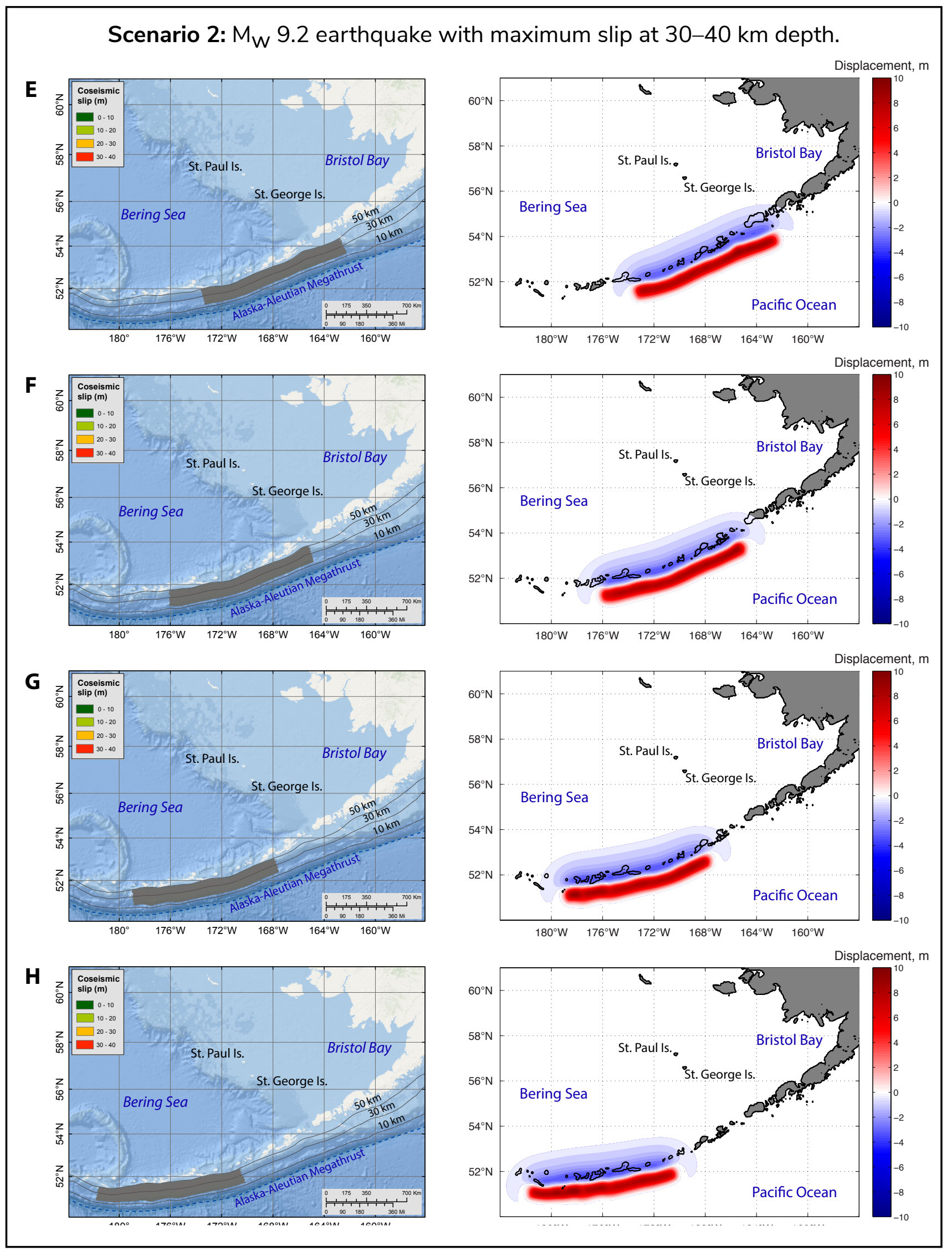

Figure 4B. Slip distributions (left column) and vertical coseismic deformations (right column) corresponding to scenario 2. Blue areas are associated with regional coseismic ground subsidence; areas of uplift are shown in red. 


\section{Landslide Tsunami Sources}

In addition to the hypothetical tectonic scenarios, we consider two submarine landslide scenarios at the southern end of the Beringian margin that could potentially generate hazardous waves along the shores of Bristol Bay and the Pribilof Islands. GLORIA sidescan sonar imagery of the eastern edge of the Umnak Plateau (fig. 2) shows a large mass failure with an estimated volume of sediment of about $20 \mathrm{~km}^{3}\left(5 \mathrm{mi}^{3}\right.$ ) (Cooper and others, 1986). Carlson and others (1991) suggest that the sediment flow originated in the Bering Canyon. An even larger mass failure was imaged by the GLORIA system on the western edge of the Umnak Plateau with an estimated volume of sediment of about 195 $\mathrm{km}^{3}$ (47 $\left.\mathrm{mi}^{3}\right)$. However, this volume includes the upper $150 \mathrm{~m}(492 \mathrm{ft})$ of the sea floor that has been mobilized in the mass failure, therefore incorporating additional material into the slide mass after the initial failure. Because it is not known what percentage of the slide volume represents the sediment added during the slide motion, we assume the initial slide volume for both scenarios is similar to that of the Bering Canyon slide. Based on this data, we construct two landslide sources located on both edges of the Umnak Plateau. The slide locations and thicknesses are shown in figure 5.
Scenario 3. An underwater slide in the Bering Canyon.
This event is an underwater slope failure in Bering Canyon (BC) along the eastern edge of the Umnak Plateau. After specifying hypothetical failure surfaces for the $B C$ slide, we assume that the slide volume is $16 \mathrm{~km}^{3}\left(3.8 \mathrm{mi}^{3}\right)$ and the maximum thickness

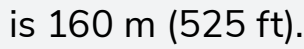

Scenario 4. An underwater slide on the western flank of the Umnak Plateau.
This event is an underwater slope failure at the western edge of Umnak Plateau (UP). After specifying hypothetical failure surfaces for the UP slide, we assume that the slide volume is 23 $\mathrm{km}^{3}\left(5.5 \mathrm{mi}^{3}\right)$ and the maximum thickness is $130 \mathrm{~m}(426.5 \mathrm{ft})$.

\section{Volcanic Tsunami Hazard}

Approximately $3.5 \mathrm{kya}$, a caldera-forming eruption of Aniakchak volcano (fig. 2) released a large-volume pyroclastic flow into the southern Bering Sea (Waythomas and Neal, 1998). Waythomas and Watts (2003) performed a numerical study of resulting tsunami waves and compared the results with the field estimates of tsunami runup. The results show that high-amplitude waves probably occurred along the southern and western shores of Nushagak Peninsula, while the tsunami energy dissipated significantly by the time the waves reached the head of Nushagak Bay near Dillingham (fig. 2). The modeled tsunami height at the head of Nushagak Bay was about 1 meter (3.3 $\mathrm{ft}$ ), and the tsunami travel time to Dillingham was about four hours. However, Waythomas and Watts
(2003) pointed out that their simulated values of tsunami runup in Nushagak Bay were underestimated by several meters compared to the height of tsunami deposits. They speculated that several factors could have contributed to this discrepancy, including sedimentation within the bay, the tidal stage when the wave arrived, and uncertainties in the exact size and orientation of the tsunami source. This study demonstrates that numerical models of tsunamis generated by past pyroclastic flows are very sensitive to a number of parameters, including minute details of the flow itself.

Currently, a detailed volcanic tsunami hazard assessment for communities in Bristol Bay cannot be completed because the locations and geometries of potential pyroclastic flows or volcanogenic mass failures (e.g., edifice collapse) are unknown. While it is 
known that volcanic eruptions have triggered tsunamigenic mass flows in many places around the world (Muhari and others, 2019; Paris and others, 2014; Latter, 1981; Kienle and others, 1987; Begét and Kienle, 1987) and numerical simulations of volcanic tsunamis are technically possible, more field data and scientific research are necessary to constrain the volcanic sources for meaningful modeling results. Even though volcanic tsunamis are known to have generated waves up to $12 \mathrm{~m}$ in Bristol Bay about $3.5 \mathrm{kya}$, due to insufficient data on the locations and volumes of these potential hazards, we do not model tsunamis generated by any volcanogenic mass flows.

\section{Numerical Model of Tsunami Propagation and Runup}

Our model has been validated through a set of analytical benchmarks and tested against labora- tory and field data (NTHMP, 2012; Synolakis and others, 2007). The tsunami scenarios that we calculate in this report are considered to be sufficient to capture the worst-case tsunami event, but there are still an infinite number of possible slip distributions and it is unknown which one will occur. Also, there are unforeseen local effects of ground shaking, such as soil compaction and landslides, that could possibly contribute to the extent of tsunami inundation. One of the limitations of the model is that it does not take into account the periodic change of sea level due to tides. We conducted all model runs using bathymetric data that correspond to mean higher high water (MHHW). As a result, the elevation of the inundation line could be lower or slightly higher than that given in this report, depending on the tides at the time

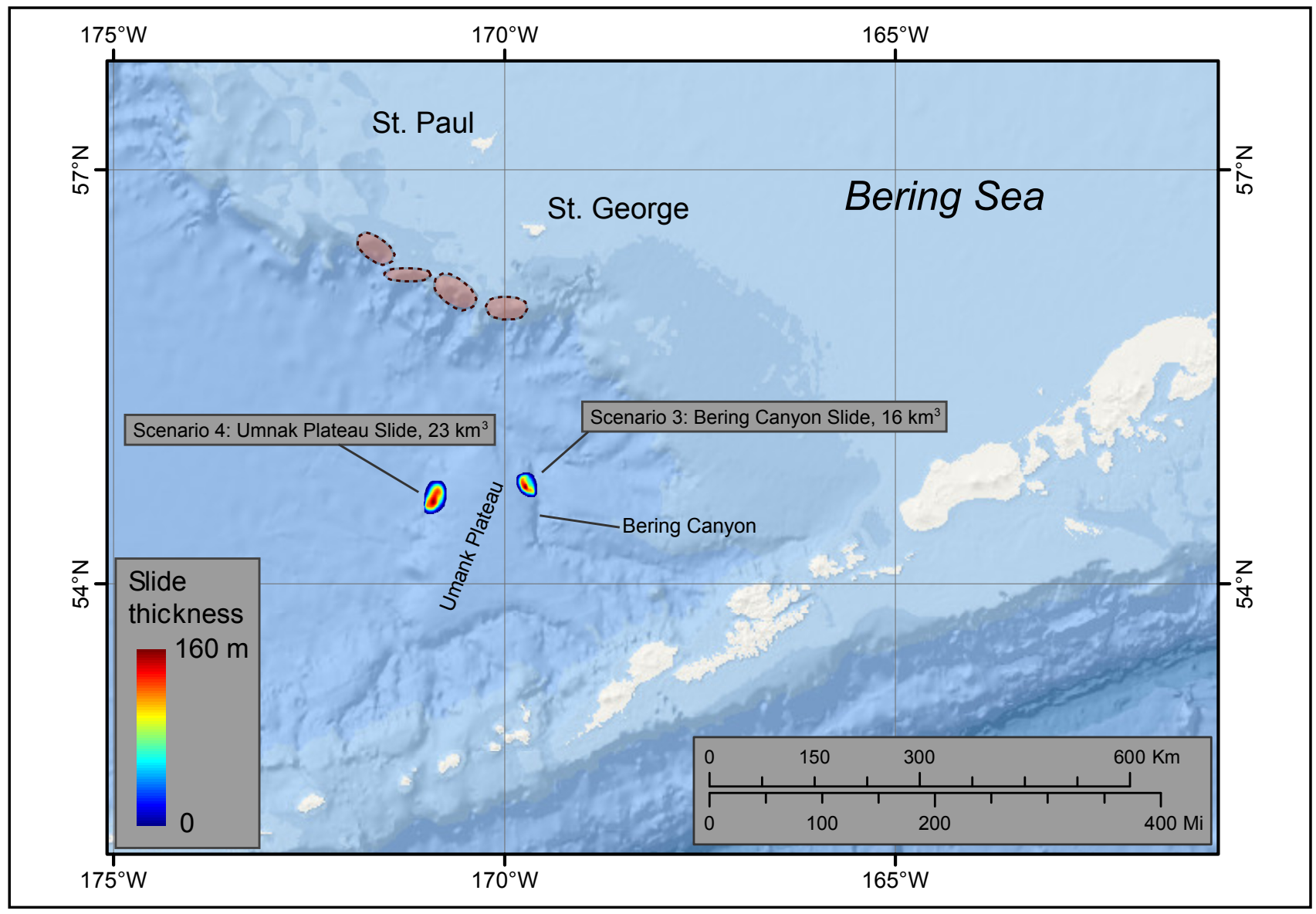

Figure 5. Locations and initial landslide thicknesses for two hypothetical landslide scenarios: scenario 3, an underwater slide in the Bering Canyon, and scenario 4, an underwater slide off the Umnak Plateau. Four pink ovals indicate locations of hypothetical landslides off the continental slope south of St. Paul and St. George islands. 
of a tsunami. A detailed description of the model is given in Nicolsky and others (2011), and the application of the model to tsunami inundation mapping of Alaska coastal communities, including its assumptions and limitations, is described in a number of previous tsunami reports-for example Nicolsky and others (2018) and Suleimani and others (2019).

To simulate landslide-generated tsunamis, we follow the methodology outlined in the tsunami hazard report for Juneau (Nicolsky and others, 2017). Specifically, we use a numerical model developed by Kirby and others (2016) with two fully coupled components: a depth-integrated layer of Newtonian viscous fluid for the landslide model (Fine and others, 1998; Jiang and LeBlond, 1992) and a shock-capturing Non-Hydrostatic Wave (NHWAVE) model by Ma and others, 2012. At some moment in time, the water level and water velocities (depth-averaged across all layers in NHWAVE) are used as initial conditions for the FUNWAVE model of Shi and others (2012). FUNWAVE then models further propagation of the landslide-generated waves away from the source area. More details regarding the coupling and the choice of parameters used to simulate landslide dynamics can be found in Nicolsky and others (2017).

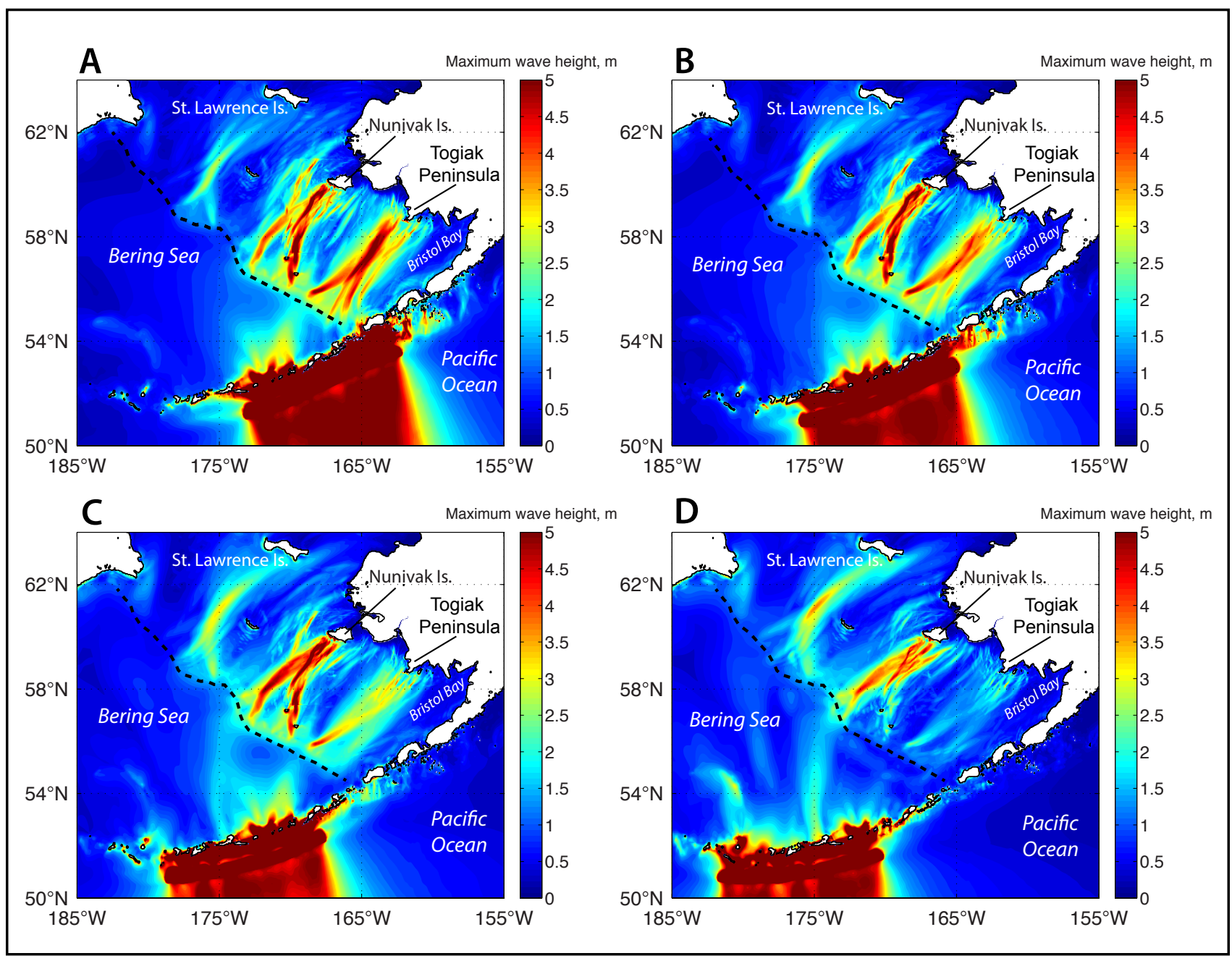

Figure 6. Calculated maximum tsunami amplitudes in the Bering Sea corresponding to the four ruptures of scenario 1 . The black dashed line indicates the boundary of the Bering Sea shelf. 


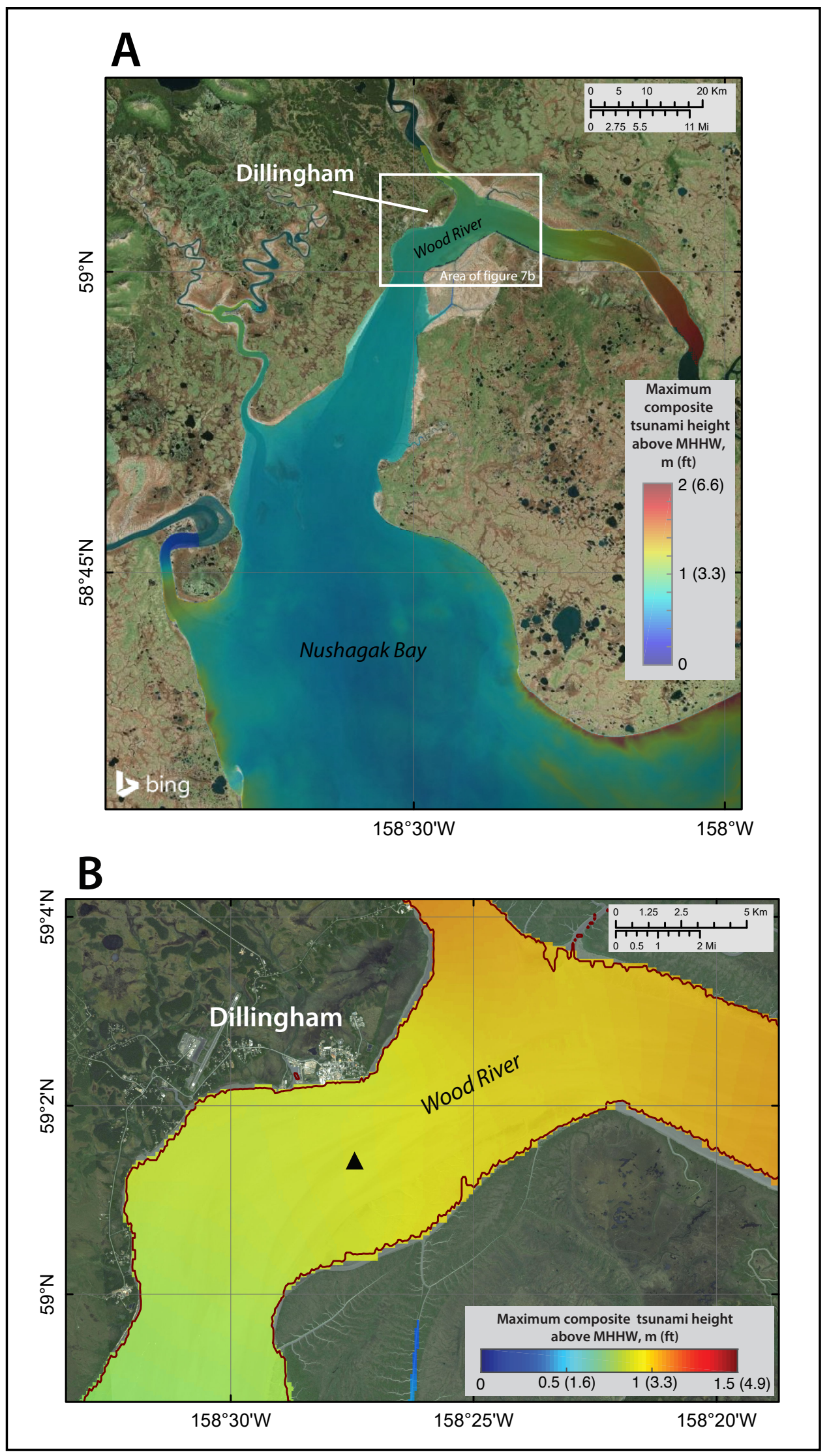

Figure 7. Maximum composite tsunami height at Dillingham. The black triangle indicates the location of the time series point, and the dark red contour is the MHHW shoreline. 


\section{MODELING RESULTS}

\section{Tectonic Tsunami Scenarios}

We performed numerical calculations for all tectonic scenarios described above. For every scenario, we modeled the water dynamics in each grid listed in table 2, and computed maximum tsunami wave heights in the level 3 grids for
Dillingham, Nelson Lagoon, and Platinum. For the communities of St. Paul and St. George we calculated the extent of tsunami inundation using the level 4 grids. Each model run was performed for 18 hours of tsunami propagation in order to account for all waves in the wave train, as well as for secondary (reflected) waves. To analyze

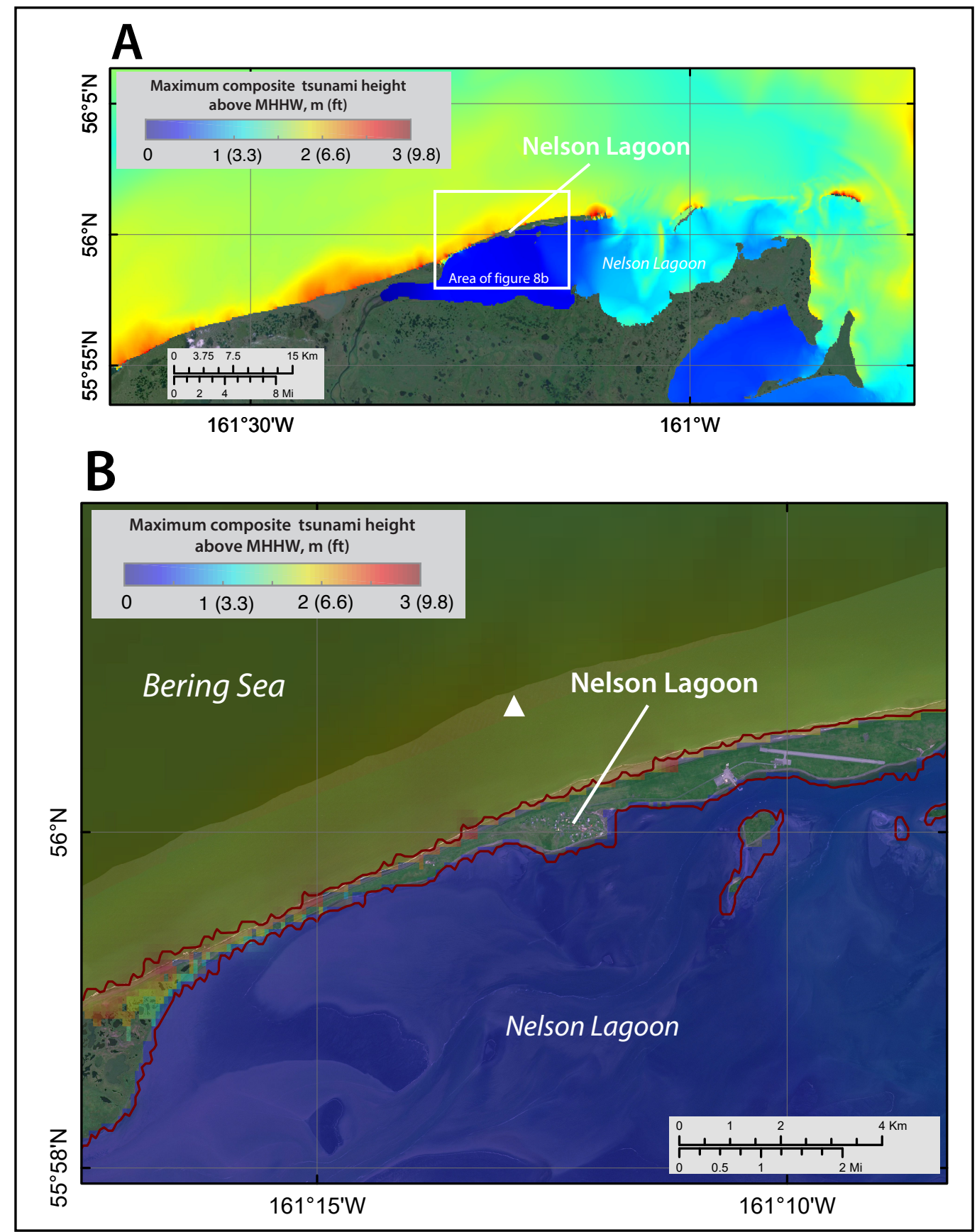

Figure 8. Maximum composite tsunami height at Nelson Lagoon. The black triangle indicates the location of the time series point, and the dark red contour is the MHHW shoreline. 


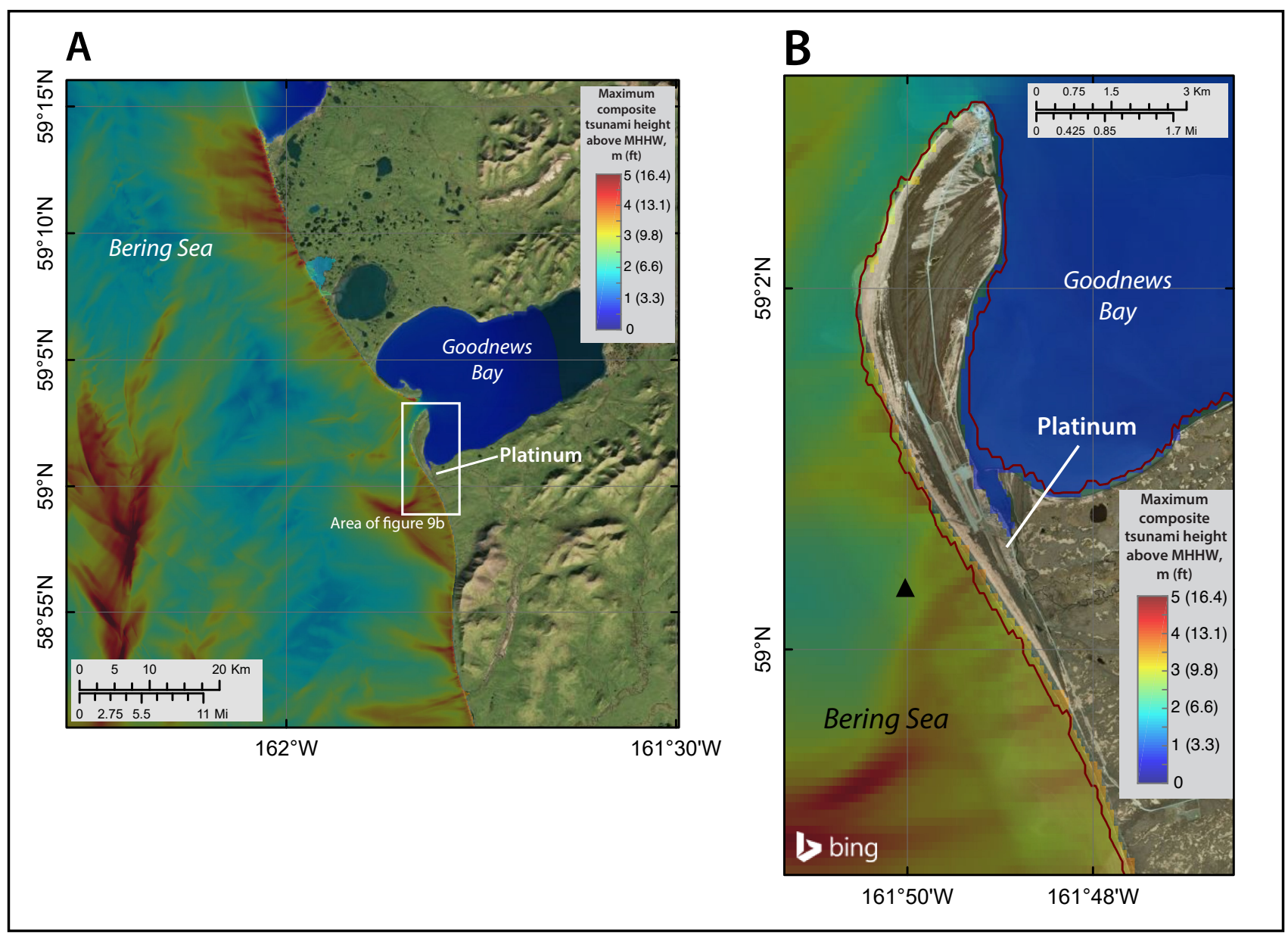

Figure 9. Maximum composite tsunami height at Platinum. The black triangle indicates the location of the time series point, and the dark red contour is the MHHW shoreline.

the directivity effects caused by positioning the tsunami source in different segments of the Aleutian arc, we plotted maximum tsunami amplitudes in the Bering Sea corresponding to the four ruptures of scenario 1 (fig. 6). The results show that for every location of the tsunami source, Bristol Bay is located in the "shadow" of the tsunami energy field. Amplitudes are relatively low in the western part of the Bering Sea, but tsunami energy increases when the waves enter the shallow waters of the Bering Sea shelf. From there, the tsunami energy splits into three major beamsthe northern one is directed towards St. Lawrence Island, the middle one is directed toward Nunivak Island, and the southern beam is pointing to the Togiak Peninsula, where Platinum is located. St. Paul and St. George islands are both located in the area of large tsunami amplitudes. The ruptures of scenario 2 generate a similar pattern of energy distribution in the Bering Sea.

Figures 7-9 show the maximum composite tsunami heights for all tectonic scenarios, calculated in the vicinity of Dillingham, Nelson Lagoon, and Platinum, respectively. The absolute maximum value of the tsunami height, multiplied by a safety factor of 1.3, results in a maximum assumed runup height of $1.4 \mathrm{~m}(4.6 \mathrm{ft})$ for the community of Dillingham, $3.5 \mathrm{~m}(11.5 \mathrm{ft})$ for Nelson Lagoon, and $4.9 \mathrm{~m}(16 \mathrm{ft})$ for Platinum. For these communities, we illustrate the maximum assumed wave runup on land by drawing an elevation contour on the community topographic map that corresponds to the maximum modeled wave height offshore. This contour approximates the boundary of the 


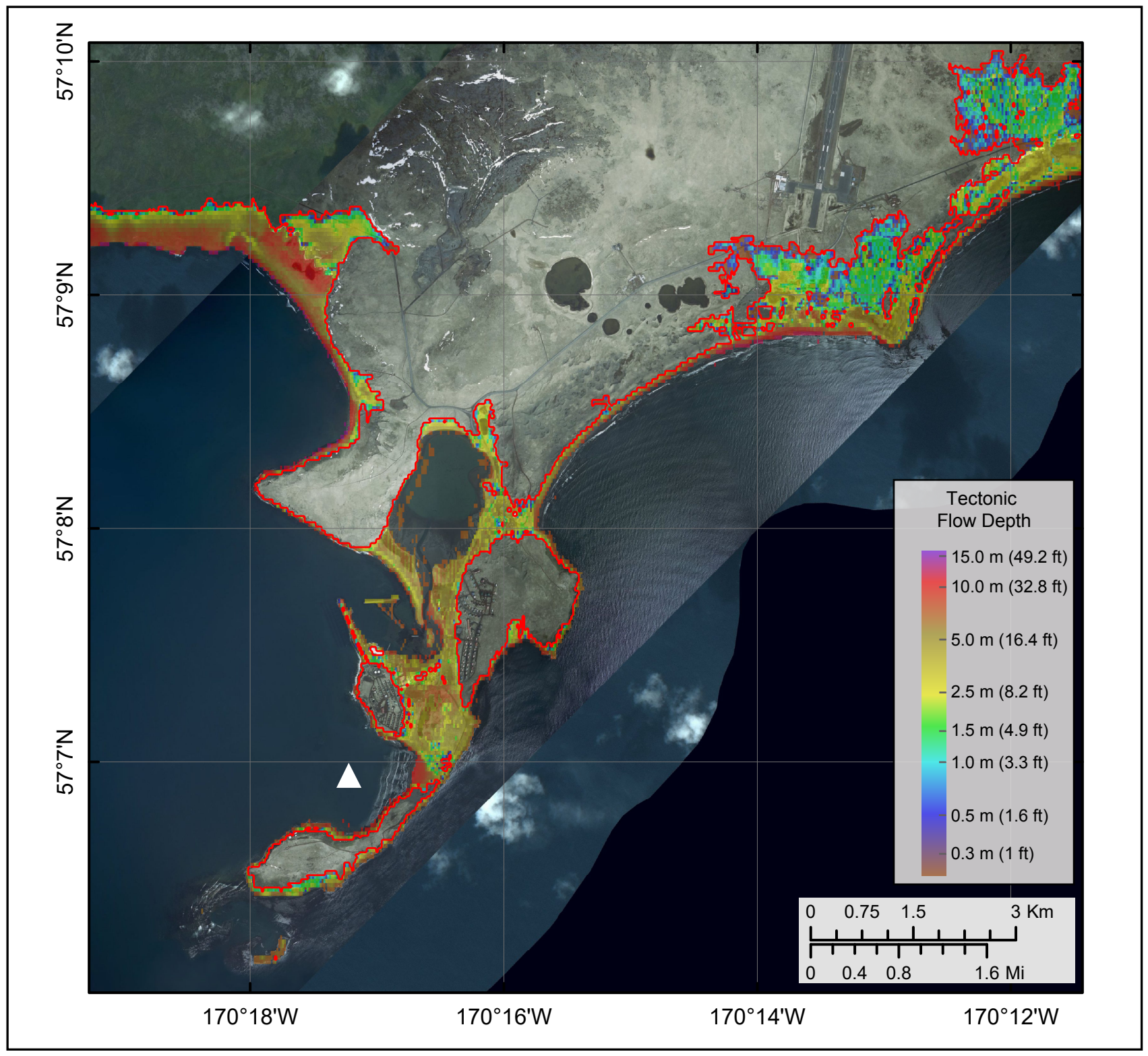

Figure 10. Maximum composite flow depths over dry land at St. Paul calculated from all tectonic scenarios. The white triangle indicates the location of the time series point.

tsunami hazard zone, and should be used by emergency planners and public officials as a guideline in tsunami mitigation activities.

Figures 10-12 show the composite tsunami inundation line and flow depths over dry land for the communities of St. Paul and St. George, and the St. George airport area, respectively. The maximum value of tsunami runup is $16 \mathrm{~m}(52.5 \mathrm{ft})$ at St. Paul, $5 \mathrm{~m} \mathrm{(16} \mathrm{ft)} \mathrm{at} \mathrm{St.} \mathrm{George,} \mathrm{and} 11 \mathrm{~m}(36$ $\mathrm{ft})$ near St. George airport.
To help emergency managers assess the tsunami hazard in the communities, we supplement the hazard maps with a time series of the modeled water level at a near-shore location in each community. These locations are shown by triangles in figures $7-12$, and the time series plots are shown in figure 13. Zero time corresponds to the time when the earthquake occurs. In order to compare the height of arriving tsunamis for different scenarios that result in different values of land subsidence, we use a vertical datum with 


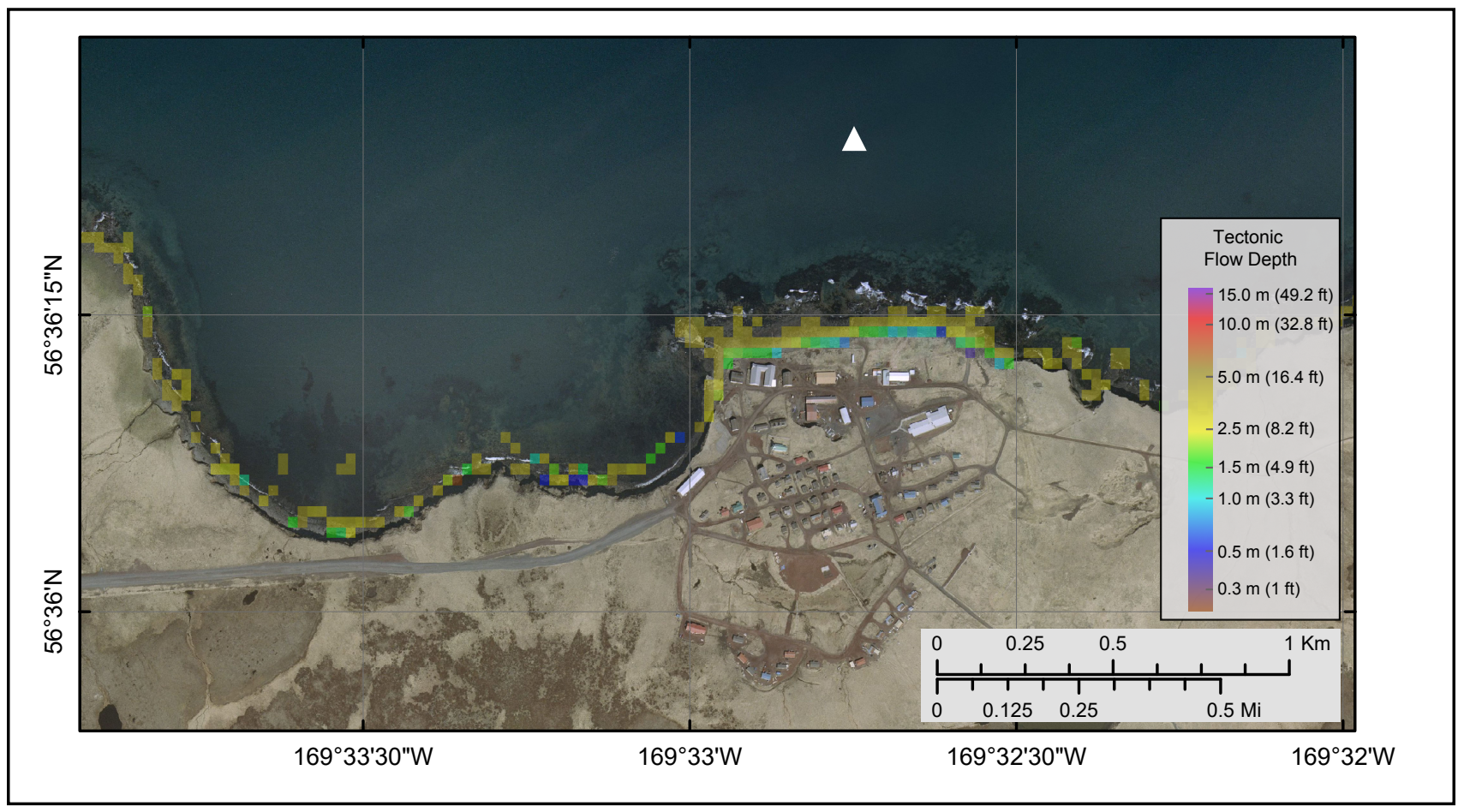

Figure 11. Maximum composite flow depths over dry land at St. George calculated from all tectonic scenarios. The white triangle indicates the location of the time series point.

a zero mark corresponding to the post-earthquake sea level. Analysis of the time series plot shows that the first wave arrives in Dillingham about 10 hours after the earthquake, in Nelson Lagoon after about five hours, and in Platinum after about seven hours. Waves will arrive at the Pribilof Islands communities much sooner-less than two hours after the earthquake. The time series plots also demonstrate that significant waves will last for hours.

\section{Landslide Tsunami Scenarios}

We performed numerical calculations for the landslide scenarios using the methodology for coupling NHWAVE and FUNWAVE models outlined in the tsunami hazard report for Juneau (Nicolsky and others, 2017). Figures 14A and 14B show the maximum tsunami height calculated for scenarios 3 and 4, respectively. The results demonstrate that high-amplitude waves initially propagate radially away from landslide source areas but then the energy directivity pattern changes according to the location of the slide with respect to bathymetric features in the surrounding area. In both scenarios, after quick dissipation of energy in the deeper part of the Bering Sea, amplitudes increase again when the waves enter the shallow waters of the Bering Sea shelf. In both scenarios, Bristol Bay is located in the "shadow" of the tsunami energy field with wave heights of $25 \mathrm{~cm}$ or smaller. The Pribilof Islands experience relatively small wave heights as well. The difference between the scenarios is in areas of secondary amplification of the tsunami energy. In scenario 3, the western beam of tsunami energy splits into two rays directed toward the islands south of the Umnak Plateau, where the tsunami energy is amplified due to shallow bathymetry. The eastern beam of tsunami energy splits into four rays that are amplified due to entering the shallow area of the Bering Sea shelf. In scenario 4, only the eastern beam of energy splits into two rays-one follows the shallow edge of the Bering Sea shelf and then dissipates in Bristol Bay, the second follows the shallow waters along the edge of the Umnak Plateau and then amplifies at the northern shore of Umnak Island. 


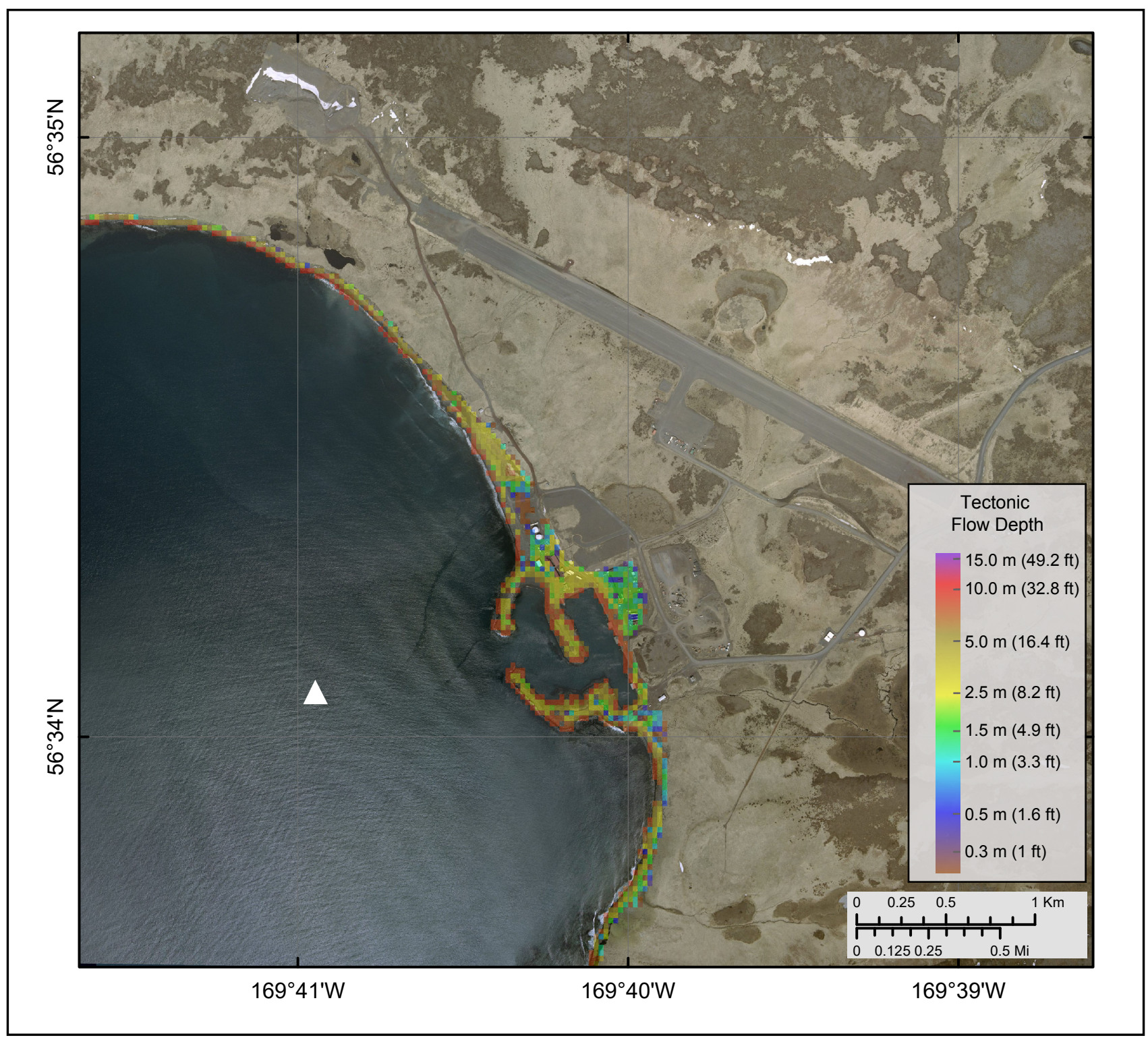

Figure 12. Maximum composite flow depths over dry land in the area of St. George airport calculated from all tectonic scenarios. The white triangle indicates the location of the time series point.

The different patterns of tsunami energy for the two landslide scenarios clearly demonstrate that the modeling results are highly sensitive to the location of the slide along the shelf boundary. In addition to landslide scenarios 3 and 4, we performed a numerical modeling study of tsunamis generated by four landslides slumping off the continental slope in the area south of St. George and St. Paul islands (fig. 5); the volume of each slide is about $100 \mathrm{~km}^{3}\left(24 \mathrm{mi}^{3}\right)$. The results of this study were inconclusive, showing that the wave height at the southern shore of St. Paul
Island could range from 8 to 30 meters (26 to 98 $\mathrm{ft}$ ), depending on the location of the slide. However, there are no constraints to define the likelihood of each of the considered slides.

The volume of the slide is another critical parameter that determines the magnitude of tsunami runup at specific coastal locations. For example, our preliminary modeling of a potential $200 \mathrm{~km}^{3}$ $\left(48 \mathrm{mi}^{3}\right)$ mass failure at the western edge of the Umnak Plateau (Carlson and others, 1991) shows that a simulated wave in Unalaska/Dutch Harbor is 

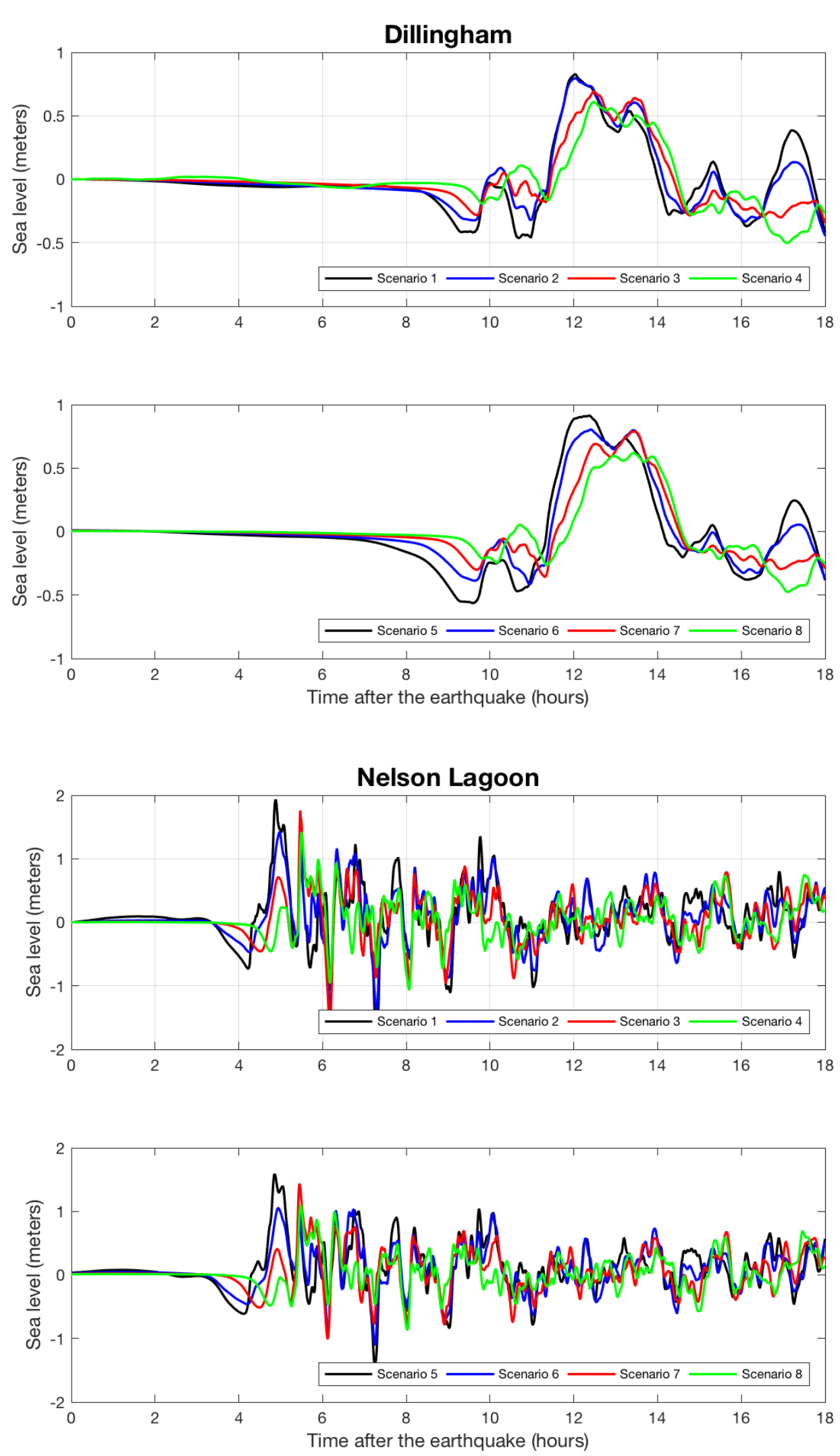

Figure 13A, B. Time series of water level for all tectonic scenarios at Dilligham (A) and Nelson Lagoon (B), calculated at the locations shown as black triangles in figures 7-9, and as white triangles in figures 10-12. 

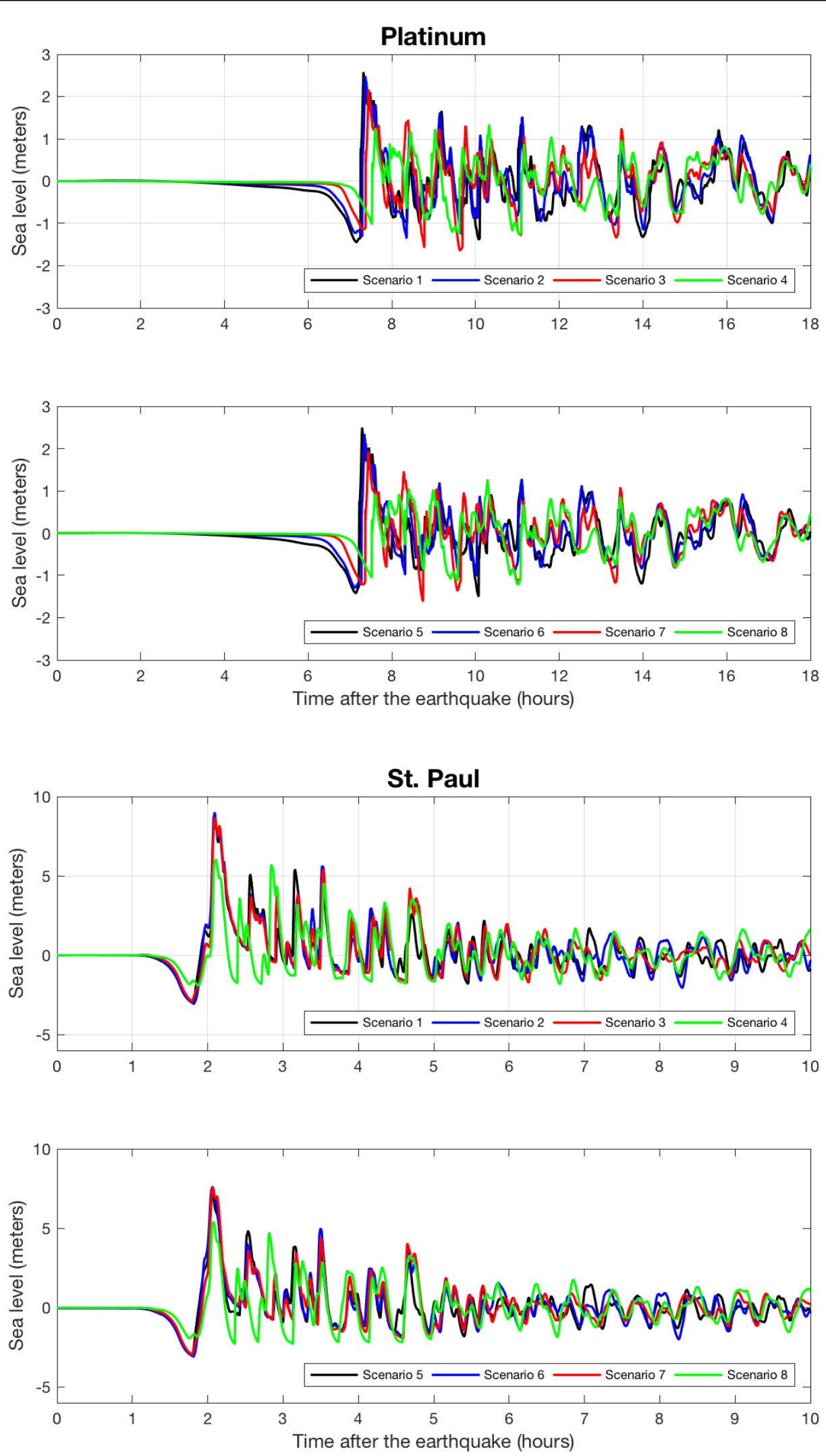

Figure 13C, D. Time series of water level for all tectonic scenarios at Platinum (C) and St. Paul (D), calculated at the locations shown as black triangles in figures 7-9, and as white triangles in figures 10-12. 

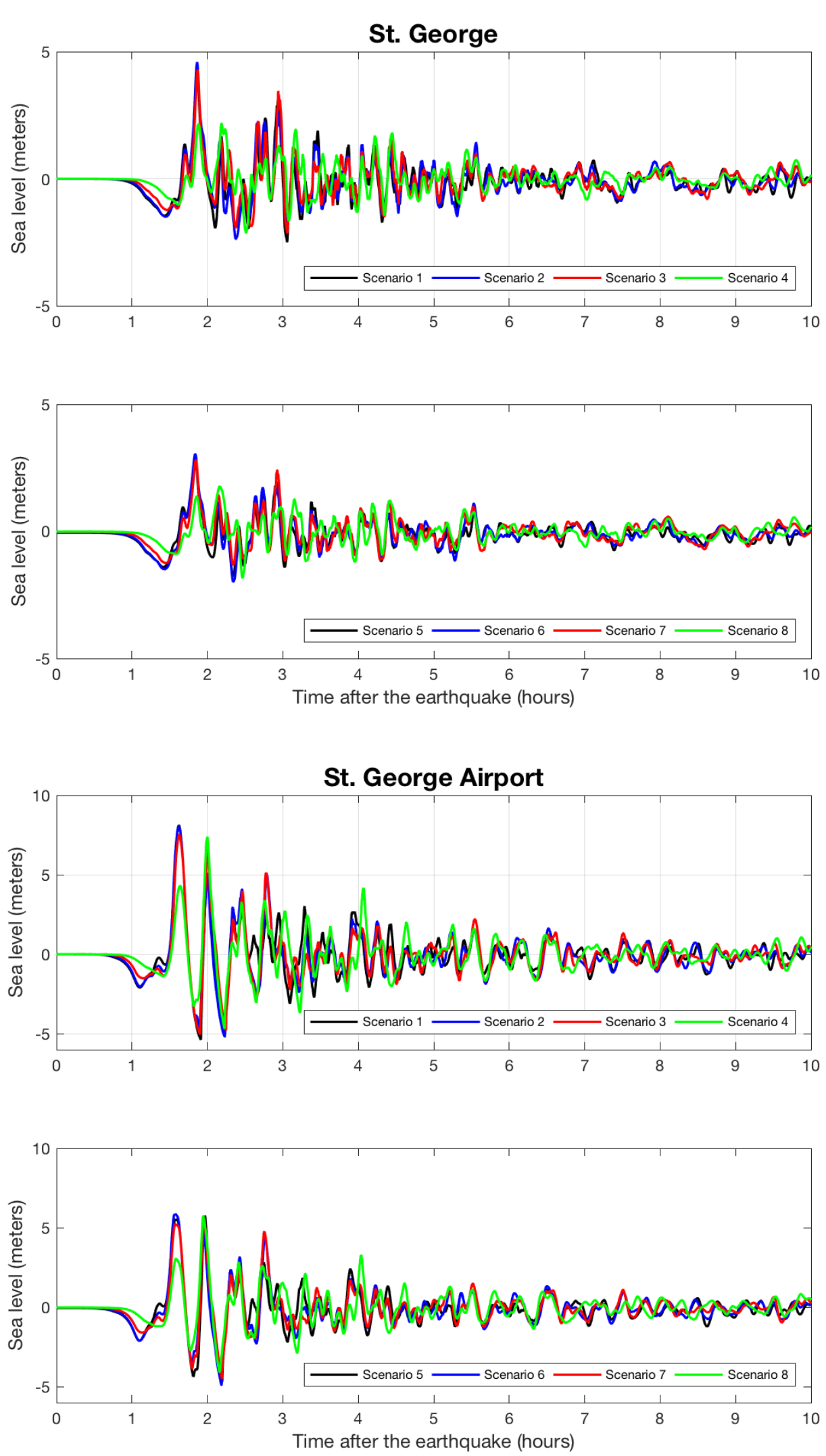

Figure 13E, F. Time series of water level for all tectonic scenarios at St. George (E) and St. George Airport (F), calculated at the locations shown as black triangles in figures 7-9, and as white triangles in figures 10-12. 


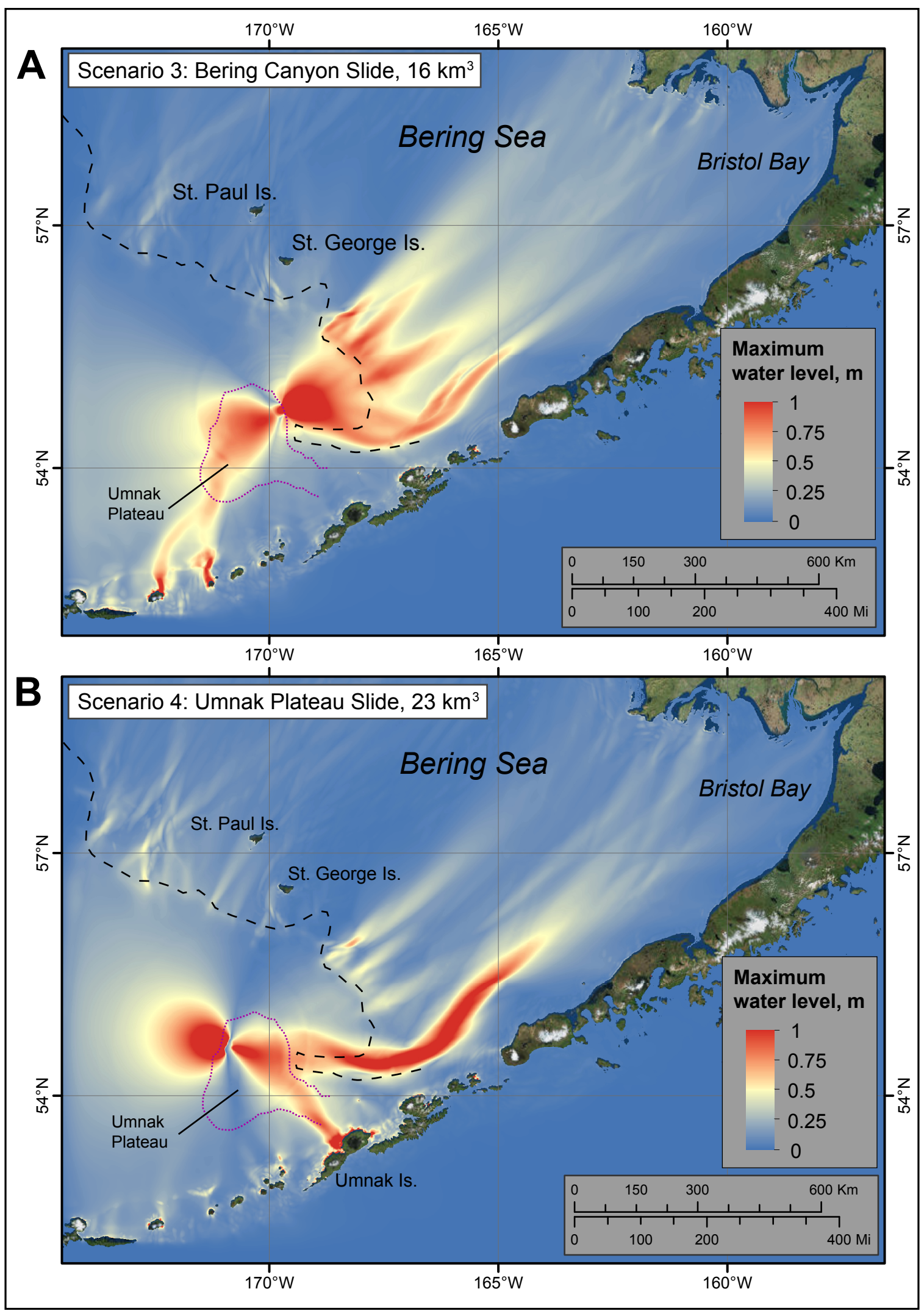

Figure 14. Maximum wave height in the Bering Sea and Bristol Bay for landslide scenarios. A. Scenario 3 : an underwater slide in the Bering Canyon. B. Scenario 4: an underwater slide off the Umnak Plateau. The edge of the Bering Sea shelf is shown by the black dashed line. The Umnak Plateau is outlined by the purple dotted line. 
similar in height to a tsunami generated by a $\mathrm{M}_{\mathrm{W}}$ 9.1 earthquake along the Fox Islands. In comparison, landslide-generated wave heights in the present study do not exceed $1 \mathrm{~m}$ because the volumes of the slides are about 10 times smaller, $16 \mathrm{~km}^{3}(3.8$ $\left.\mathrm{mi}^{3}\right)$ and $23 \mathrm{~km}^{3}\left(5.5 \mathrm{mi}^{3}\right)$. This demonstrates that more geotechnical data and research are required to further constrain potential slide locations and their volumes before we can accurately estimate tsunami inundation zones in communities of Bristol Bay and the Pribilof Islands.

\section{SUMMARY}

We present results of modeling megathrust earthquake-generated tsunami propagation through the Bering Sea and their effects on the communities of Dillingham, Nelson Lagoon, Platinum, St. Paul, and St. George. We numerically model tsunami waves generated by local hypothetical tectonic sources, analyze tsunami wave dynamics in the vicinity of the communities, and develop tsunami hazard maps. Specifically, we compute the composite maximum wave height from all considered scenarios and follow the NTHMP guidelines to extrapolate the modeling data on land for estimation of tsunami inundation. The maximum assumed runup heights (that include the additional 30 percent safety factor) are $1.4 \mathrm{~m}(4.6 \mathrm{ft})$ for Dillingham, $3.5 \mathrm{~m}(11.5 \mathrm{ft})$ for Neslon Lagoon, and $4.9 \mathrm{~m}(16 \mathrm{ft})$ for Platinum. The maximum calculated value of tsunami runup at St. Paul is $16 \mathrm{~m}$ $(52.5 \mathrm{ft}), 5 \mathrm{~m}(16 \mathrm{ft})$ at St. George, and $11 \mathrm{~m} \mathrm{(36}$ $\mathrm{ft})$ near the St. George airport.

Volcanic tsunamis are known to have generated waves up to $12 \mathrm{~m}$ in Bristol Bay about 3.5 kya due to a caldera-forming eruption of Aniakchak Volcano. A previous numerical modeling study by Waythomas and Watts (2003) underestimated values of tsunami runup in Nushagak Bay by several meters compared to the hight of the tsunami deposits. The study demonstrated that numerical models of tsunamis generated by past pyroclastic flows are very sensitive to a number of parameters. We do not perform a detailed volcanic tsunami hazard assessment for communities in Bristol Bay in this report because the locations and geometries of potential pyroclastic flows or volcanogenic mass failures (e.g., edifice collapse) are unknown.

The tsunami inundation approximations shown on the tsunami hazard maps have been completed using the best information available and are believed to be accurate; however, their preparation required many assumptions. In this assessment, we estimate the potential tsunami inundation zone based on two significant tsunami scenarios. Hence, the modeled tsunami inundation cannot be considered exhaustive, but nevertheless the modeling results are thought to provide a sound approximation of potential tsunami inundation zones. We also note that actual conditions during a tsunami event may vary from those considered, so the accuracy cannot be guaranteed. The shown inundation limits should be used only as a guideline for emergency planning and response action. Actual areas inundated will depend on specifics of the earthquake deformation, land construction, and tide level and may differ from areas shown on the map. The information on the hazard maps is intended to assist state and local agencies in planning emergency evacuation and tsunami response actions in the event of a major tsunamigenic earthquake. These results are not intended for land-use regulation or building-code development.

\section{ACKNOWLEDGMENTS}

This project received support from the National Oceanic and Atmospheric Administration (NOAA) under grant awards: NA16NWS4670030, NA17NWS4670006, and NA19NWS4670008 with the State of Alaska's Division of Homeland Security \& Emergency Management. Numerical calculations for this work were supported by a grant of High Performance Computing (HPC) resources from the Arctic Region Supercomputing Center (ARSC) at the University of Alaska Fairbanks. 


\section{REFERENCES}

Allen, B.M., 1994, Holocene tephra and tsunami deposits along western Nushagak Bay, southwestern Alaska [abs.]: Geological Society of America Abstracts with Programs, v. 26, no. 3, p. 2.

Armes, C.J., 1996, Comparison of Holocene tsunami and modern storm-overwash deposits, northern Bristol Bay, southwestern Alaska [abs.]: Geological Society of America Abstracts with Programs, v. 28, no. 3, p. 35.

Begét, J.E. and Kienle, Jürgen, 1992, Cyclic formation of debris avalanches at Mount St. Augustine Volcano: Nature, v. 356, p. 701-704.

Bryn, Petter, Berg, Kjell, Stoker, M.S., Haflidason, Haflidi, and Solheim, Anders, 2005, Contouritic deposition and its relevance for the mass wasting record along the Mid-Norwegian Margin: Marine and Petroleum Geology, v. 22, no. 1-2, p. 85-96. doi.org/10.1016/j.marpetgeo.2004.10.012

Butler, Rhett, 2014, Great Aleutian tsunamis: Honolulu, HI, University of Hawai'i at Manoa, Hawai'i Institute of Geophysics \& Planetology, Peer-Reviewed Report HIGP-2014-1, 170 p. www.higp.hawaii.edu/reports/2014

Carlson, P.R., Karl, H.A., and Edwards, B.D., 1991, Mass sediment failure and transport features revealed by acoustic techniques, Beringian margin, Bering Sea, Alaska: Marine Geotechnology, v. 10, no. 1-2, p. 33-51. doi. org/10.1080/10641199109379881

Cooper, A.K., Stevenson, A.J., Kenyon, N.H., and Bishop, D., 1986, GLORIA study of the Exclusive Economic Zone off Alaska-southern Bering Sea: initial report for cruise F4-86-BS, 3 September to 30 September 1986: U.S. Geological Survey Open-file Report 86-596, 11 p.

Cox, D.C., 1984, Probable Aleutian source of the tsunami observed in August 1872 in Hawaii, Oregon, and California: Science of Tsunami Hazards, v. 2, no. 2, p. 79-94.

Dunbar, P.K., and Weaver, C.S., 2008, U.S. states and territories national tsunami hazard assessment- Historical record and sources for waves:
National Oceanic and Atmospheric Administration and U.S. Geological Survey, Technical Report, 59 p. nthmp.tsunami.gov/documents/ Tsunami_Assess

Estabrook, C.H., Jacob, K.H., and Sykes, L.R., 1994, Body wave and surface wave analysis of large and great earthquakes along the eastern Aleutian arc, 1923-1993; Implications for future events: Journal of Geophysical Research, v. 99, no. B6, p. 11,643-11,662.

Fine, I.V., Rabinovich, A.B., Bornhold, R.E. Thompson, R.E., and Kulikov, E.A., 2005, The Grand Banks landslide-generated tsunami of November 18, 1929: preliminary analysis and numerical modeling: Marine Geology, v. 215, p. 45-57. doi.org/10.1016/j.margeo.2004.11.007

Fine, I. V., Rabinovich, A.B., Kulikov, E.A., Thomson, R.E., and Bornhold, B.D., 1998, Numerical modeling of landslide-generated tsunamis with application to the Skagway Harbor tsunami of November 3, 1994, in Proceedings of International Conference on Tsunamis: Paris, p. 211-223.

Freund, L.B., and Barnett, D.M., 1976, A two-dimensional analysis of surface deformation due to dip-slip faulting: Bulletin of the Seismological Society of America, v. 66, no. 3, p. 667-675.

Freymueller, J.T., Woodard, Hilary, Cohen, S.C., Cross, Ryan, Elliott, Julie, Larsen, C.F., Hreinsdóttir, Sigrún, and Zweck, Chris, 2008, Active deformation processes in Alaska, based on 15 years of GPS measurements, in Freymueller, J.T., Haeussler, P.J., Wesson, R.L., Ekström, Göran, Active tectonics and seismic potential of Alaska: American Geophysical Union Geophysical Monograph Series, v. 179, p. 1-42. doi. org/10.1029/GM179

Geist, E.L., and Parsons, Tom, 2006, Probabilistic analysis of tsunami hazards: Natural Hazards. v. 37, no. 3, p. 277-314. dx.doi.org/10.1007/ s11069-005-4646-z

Hayes, G.P., Wald, D.J., and Johnson, R.L., 2012, Slab 1.0: A three-dimensional model of global subduction zone geometries: Journal of Geophysical Research, v. 117, no. B01, p. 302. doi. org/10.1029/2011JB008524 
Jiang, L., and LeBlond, P.H., 1992, The coupling of a submarine slide and the surface waves which it generates: Journal of Geophysical Research, v. 97, no. C8, p. 12,731-12,744. doi.org/10.1029/ 92JC00912

Johnson, J.M., Tanioka, Yuichiro, Ruff, L.J., Satake, Kenji, Kanamori, Hiroo, and Sykes, L.R., 1994, The 1957 great Aleutian earthquake: Pure and Applied Geophysics, v. 142 no. 1, p. 3-28. doi.org/10.1007/BF00875966

Kanamori, Hiroo, 1970, The Alaska earthquake of 1964-Radiation of long-period surface waves and source mechanism: Journal of Geophysical Research, v. 75, no. 26, p. 5,029-5,040. doi. org/10.1029/JB075i026p05029

Kienle, Jürgen, Kowalik, Zygmunt, and Murty, T.S., 1987, Tsunamis generated by eruptions from Mount St. Augustine Volcano, Alaska: Science, v. 236, p. 1,442-1,447.

Kirby, J.T., Shi, Fengyan, Nicolsky, D.J., and Misra, Shubhra, 2016, The 27 April 1975 Kitimat, British Columbia submarine landslide tsunami-A comparison of modeling approaches: Landslides, v. 13, no. 6, p. 1,421-1,434. doi. org/10.1007/s10346-016-0682-x

Knapp, Gunnar, Guetttabi, Mouhcine, and Goldsmith, Scott, 2013, The Economic Importance of the Bristol Bay Salmon Industry: Institute of Social and Economic Research, University of Alaska Anchorage. www.bbrsda.com/wp-content/uploads/2013/05/Economic-Importance-of-Bristol-Bay-Full-Report.pdf

Lander, J.F., 1996, Tsunamis affecting Alaska, 17371996: Boulder, CO, NOAA National Geophysical Data Center (NGDC), Key to Geophysical Research Documentation, v. 31, 195 p.

Latter, J.H., 1981, Tsunamis of volcanic origin: Summary of causes, with particular reference to Krakatoa, 1883: Bulletin Volcanologique, v. 44, p. 467-490. doi.org/10.1007/BF02600578

Lea, P.D., 1989, Holocene tsunami deposits in coastal peatlands, northeastern Bristol Bay, southwestern Alaska [abs.]: Geological Society of America Abstracts with Programs, v. 21, no. 6, p. 344.

Lee, Homa, Ryan, Holly, Kayen, R.E., Haeussler, P.J., Dartnell, Peter, and Hampton, M.A., 2006,
Varieties of submarine failure morphologies of seismically-induced landslides in Alaskan fords: Norwegian Journal of Geology (Norsk Geologisk Tidsskrift), v. 86, no. 3, p. 221-230.

Lim, E., Eakins, B.W., and Wigley, R., 2011, Coastal relief model of southern Alaska-Procedures, data sources and analysis: National Oceanic and Atmospheric Administration (NOAA) Technical Memorandum NESDIS NGDC-43, 22 p.

Lopez, A.M., and Okal, E.A., 2006, A seismological reassessment of the source of the 1946 Aleutian 'tsunami' earthquake: Geophysical Journal International, v. 165 , no. 3, p. 835-849. doi. org/10.1111/j.1365-246X.2006.02899.x

Ma, Gangfeng, Shi, Fengyan, and Kirby, J.T., 2012, Shock-capturing non-hydrostatic model for fully dispersive surface wave processes: Ocean Modelling, v. 43-44, p. 22-35. doi.org/10.1016/j.ocemod.2011.12.002

Muhari, Abdul, Heidarzadeh, Muhammad, Susmoro, Harjo, Nugroho, H.D., Kriswati, Estu, Supartoyo, Wijanarto, A.B., Imamura, Fumihiko, and Arikawa, Taro, 2019, The December 2018 Anak Krakatau Volcano tsunami as inferred from post-tsunami field surveys and spectral analysis: Pure and Applied Geophysics, v. 176, p. 5,219-5,233. doi.org/10.1007/ s00024-019-02358-2

National Geophysical Data Center (NGDC), 2006, 2-minute Gridded Global Relief Data (ETOPO2) v2: National Geophysical Data Center (NGDC), National Oceanic and Atmospheric Administration (NOAA). doi.org/10.7289/ V5J1012Q

National Centers for Environmental Information (NCEI)/World Data Service (WDS), in progress, Global historical tsunami database at NGDC, 2100 BC to present (interactive map): National Geophysical Data Center, NOAA. doi. org/10.7289/V5PN93H7

National Tsunami Hazard Mapping Program (NTHMP), 2010, Guidelines and best practices for tsunami inundation modeling for evacuation planning: National Oceanic and Atmospheric Administration (NOAA), NTHMP Mapping \& Modeling Subcommittee. 
2012, Proceedings and results of the 2011 NTHMP Model Benchmarking Workshop: Boulder, CO, U.S. Department of Commerce/ NOAA/NTHMP, NOAA Special Report, 436 p. nthmp.tsunami.gov

Nicolsky, D.J., Suleimani, E.N., Freymueller, J.T., and Koehler, R.D., 2015, Tsunami inundation maps of Fox Islands communities, including Dutch Harbor and Akutan, Alaska: Alaska Division of Geological \& Geophysical Surveys Report of Investigation 2015-5, 67 p., 2 sheets, scale 1:12,500. doi.org/10.14509/29414

Nicolsky, D.J., Suleimani, E.N., and Hansen, R.A., 2011, Validation and verification of a numerical model for tsunami propagation and runup: Pure and Applied Geophysics, v. 168, no. 6, p. 1,199-1,222. doi.org/10.1007/s00024-0100231-9

Nicolsky, D.J., Suleimani, E.N., Koehler, R.D., and Salisbury, J.B., 2017, Tsunami inundation maps for Juneau, Alaska: Alaska Division of Geological \& Geophysical Surveys Report of Investigation 2017-9, 66 p., 5 sheets. doi. org/10.14509/29741

2015, Tsunami inundation maps of Elfin Cove, Gustavus, and Hoonah, Alaska: Alaska Division of Geological \& Geophysical Surveys Report of Investigation 2015-1, 79 p., 3 sheets. doi.org/10.14509/29404

Nicolsky, D.J., Suleimani, E.N., and Salisbury, J.B., 2018, Tsunami inundation maps for Skagway and Haines, Alaska: Alaska Division of Geological \& Geophysical Surveys Report of Investigation 2018-2, 69 p., 3 sheets. doi. org/10.14509/30029

Okada, Yoshimitsu, 1985, Surface deformation due to shear and tensile faults in a half-space: Bulletin of the Seismological Society of America, v. 75, no. 4, p. 1,135-1,154.

Paris, Raphaël, Switzer, A.D., Belousova, Marina, Belousov, Alexander, Ontowirjo, Budianto, Whelley, P.L., and Ulvrova, Marina, 2014, Volcanic tsunami: a review of source mechanisms, past events and hazards in Southeast Asia (Indonesia, Philippines, Papua New Guinea): Natural Hazards, v. 70, p. 447-470. doi.org/10.1007/s11069-013-0822-8
Shi, Fengyan, Kirby, J.T., Harris, J.C., Geiman, J.D., and Grilli, S.T., 2012, A high-order adaptive time-stepping TVD solver for Boussinesq modeling of breaking waves and coastal inundation: Ocean Modelling, v. 43-44, p. 36-51. doi. org/10.1016/j.ocemod.2011.12.004

Suleimani, E.N., Nicolsky, D.J., and Koehler, R.D., 2015, Tsunami inundation maps of Elfin Cove, Gustavus, and Hoonah, Alaska: Alaska Division of Geological \& Geophysical Surveys Report of Investigation 2015-1, 79 p., 3 sheets. http://doi.org/10.14509/29404

Suleimani, E.N., Nicolsky, D.J., Koehler, R.D., Freymueller, J.T., and Macpherson, A.E., 2016, Tsunami inundation maps for King Cove and Cold Bay communities, Alaska: Alaska Division of Geological \& Geophysical Surveys Report of Investigation 2016-1, 73 p., 2 sheets, scale 1:12,500. doi.org/10.14509/29565

Suleimani, E.N., Nicolsky, D.J., Koehler, R.D., and Salisbury, J.B., 2018, Regional tsunami hazard assessment for Andreanof Islands, Alaska: Alaska Division of Geological \& Geophysical Surveys Report of Investigation 2017-2, 19 p., 2 sheets. doi.org/10.14509/29704

Suleimani, E.N., Salisbury, J.B., Nicolsky, D.J., and Koehler, R.D., 2019, Regional tsunami hazard assessment for selected communities on Kodiak Island, Alaska: Alaska Division of Geological \& Geophysical Surveys Report of Investigation 2019-6, 31 p., 7 sheets. doi. org/10.14509/30195

Synolakis, C.E., Bernard, E.N., Titov, V.V., Kânoğlu, U., and González, F.I., 2007, Standards, criteria, and procedures for NOAA evaluation of tsunami numerical models: Seattle, Washington, NOAA/Pacific Marine Environmental Laboratory, Technical Memorandum OAR PMEL$135,55 \mathrm{p}$.

The Sydney Morning Herald, 1910, Floods Extraordinary, Tidal Waves in Alaska, Settlement Wiped Out: The Sydney Morning Herald, New South Wales, Australia, Monday 7 November 1910, p. 7. newspapers.nla.gov.au/ndp/del/article/15190757 (Accessed June 16, 2010) 
Waythomas, C.F., and Neal, C.A., 1998, Tsunami generation by pyroclastic flow during the 3500year B.P. caldera-forming eruption of Aniakchak Volcano, Alaska: Bulletin of Volcanology, v. 60, p. 110-124.

Waythomas, C.F., Neal, C.A., McGimsey, R.G., Dorava, J.M., Lemke, K.J., and Vanderpool, A.M., 1995, Volcanogenic tsunami from Alaska volcanoes; Geologic evidence from Bristol Bay and Cook Inlet, Alaska [abs.]: Eos, Transactions, American Geophysical Union, v. 76, no. 46, Supplement, p. 291.
Waythomas, C.F., and Watts, P., 2003, Numerical simulation of tsunami generation by pyroclastic flow at Aniakchak Volcano, Alaska: Geophysical Research Letters, v. 30, no. 14, p. 1,751.

Wu, F.T., and Kanamori, Hiroo, 1973, Source mechanism of February 4, 1965, Rat Island earthquake: Journal of Geophysical Research, v. 78, no. 26, p. 6,082-6,092.

Zador, S. and Siddon, E., 2016, Ecosystem Considerations 2016: Status of the Eastern Bering Sea Marine Ecosystem. access.afsc.noaa.gov/ reem/ecoweb/index.php?ID=29 


\section{APPENDIX A}

\section{Sensitivity study}

We perform a sensitivity study to determine which rupture locations along the Aleutian arc result in the largest tsunami amplitudes at the St. Paul harbor. We use a model of the Alaska-Aleutian plate interface referred to as Slab 1.0 from Hayes and others (2012), a section of which is shown in figure A1. The plate interface is discretized into a mesh of rectangles ranging from 3 to $6 \mathrm{~km}(1.9$ to 3.7 $\mathrm{mi}$ ) in the along-strike direction of the plate interface. The upper and lower edges of each rectangle coincide with depth contours of the plate interface that are spaced at $1 \mathrm{~km}(0.6 \mathrm{mi})$. The rectangles, called subfaults, are later used to compute coseismic ground deformation (Okada, 1985). Using this discretization of the plate interface, we can model potential earthquake scenarios by first prescribing a general pattern of slip distribution in the proposed rupture, and then computing the slip at the center of each subfault using seismic moment as a constraint.

Earthquake ruptures located in different regions of the Aleutian megathrust result in different tsunami characteristics at a given community. To evaluate potential tsunami heights at St. Paul, we develop eleven different slip scenarios for a potential $\mathrm{M}_{\mathrm{W}} 8.5$ earthquake (fig. A2). The potential ruptures are placed along the Aleutian megathrust in the area between the Andreanof Islands and Alaska Peninsula (fig. 1). The relative slip distribution for all eleven cases is identical: the area of maximum slip is located in the middle of the rupture in the along-strike direction, and a symmetrical bell-type slip curve describes slip distribution in the downdip direction.

For each case, we calculate the maximum tsunami height in the St. Paul harbor (table A1). The modeled heights vary for each scenario. The

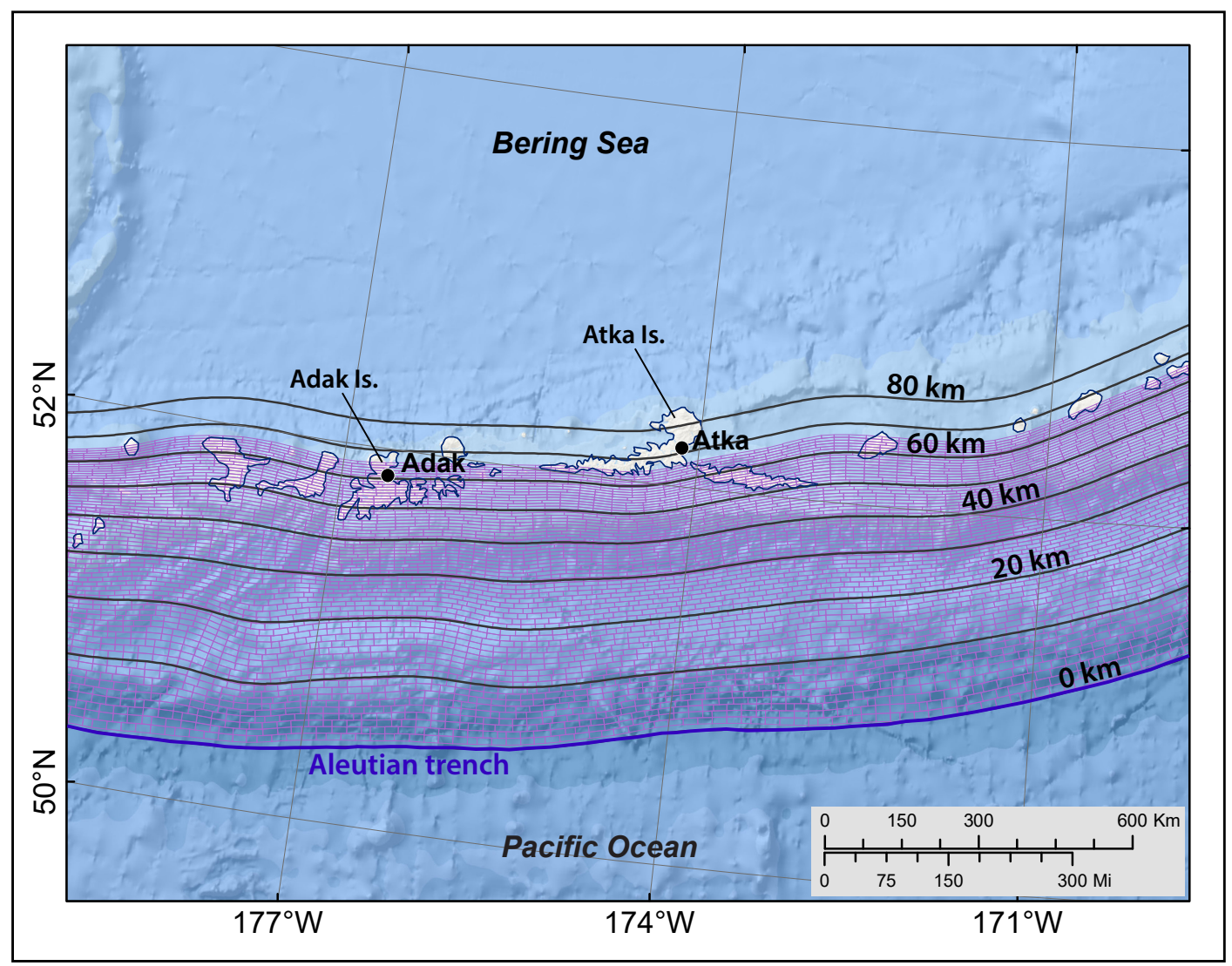

Figure A1. Discretized model of the Alaska-Aleutian plate interface. 
earthquake ruptures, located between Atka Island and Umnak Island (scenarios 5-7), produce larger waves compared to other scenarios. This is the region of the Aleutian Islands where the individual islands are much smaller, and the larger opening between them allows for more efficient penetration of tsunami energy from the Pacific side of the Aleutian arc into the Bering Sea. Therefore, the potential future earthquakes in this region result in greater tsunami hazard for the communities on the Pribilof Islands.

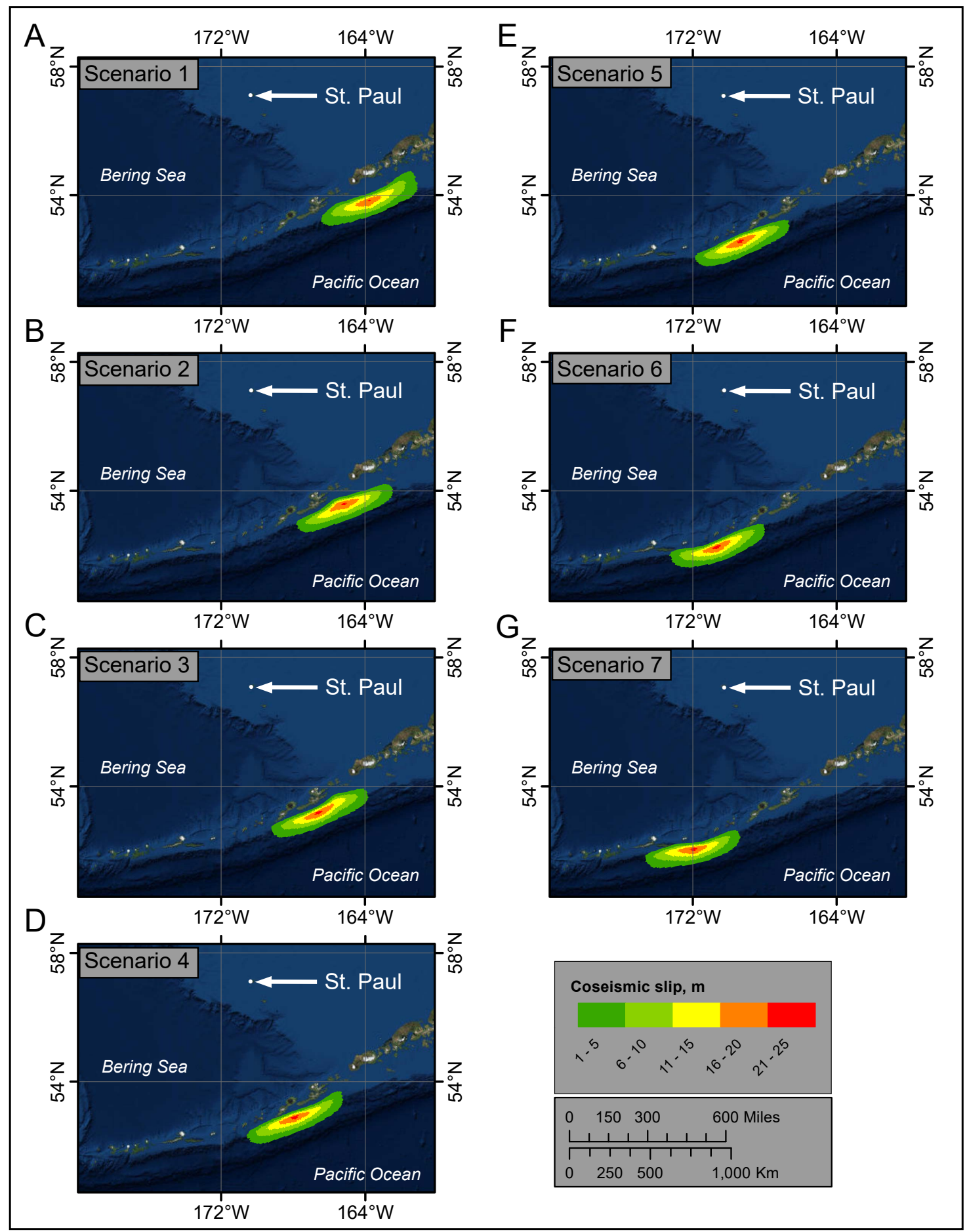

Figure A2. Slip distributions corresponding to sensitivity scenarios 1-11. 


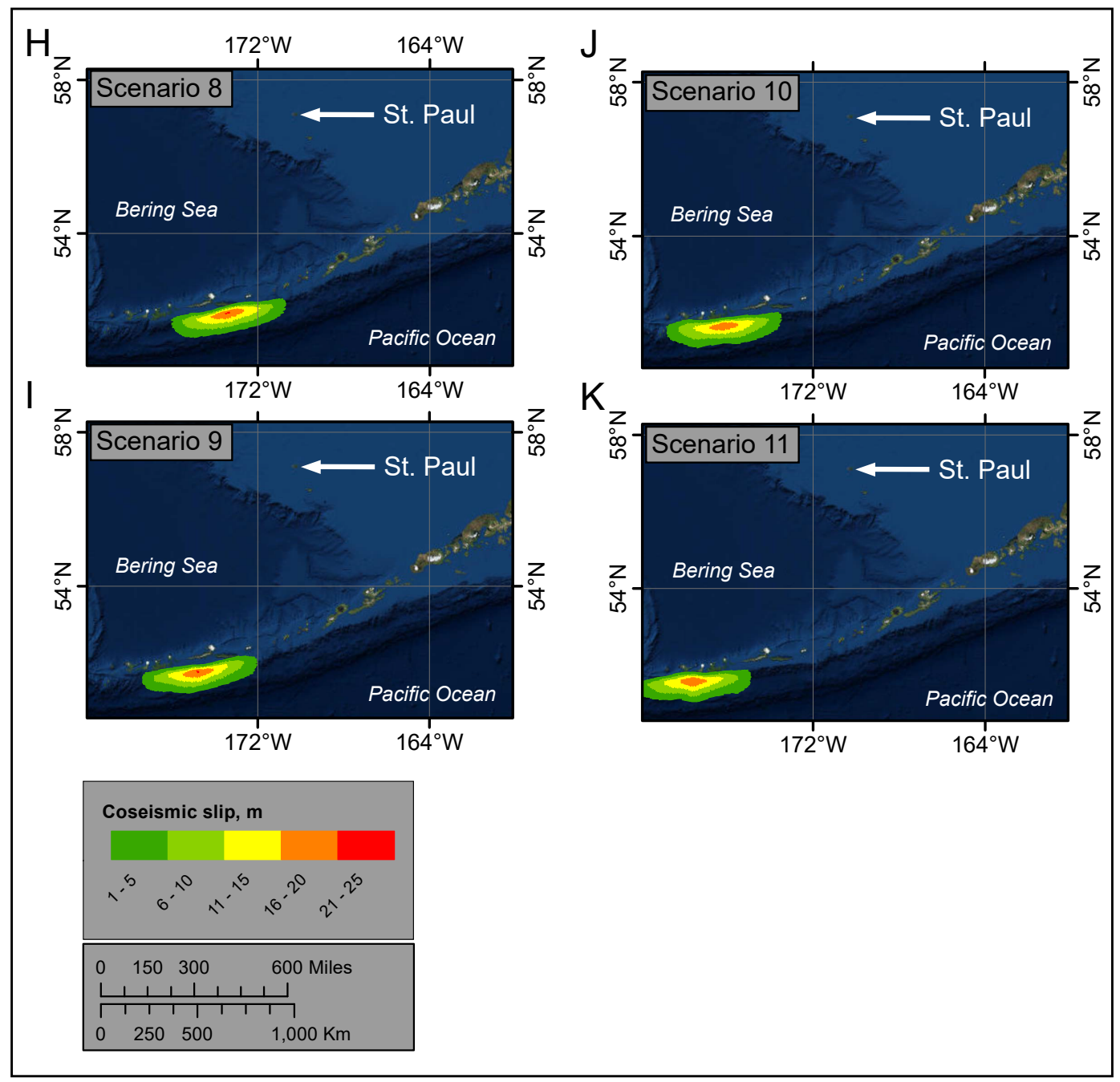

Figure A2, continued. Slip distributions corresponding to sensitivity scenarios 1-11.

Table A1. Maximum tsunami heights at the St. Paul harbor for different scenarios in the sensitivity study.

\begin{tabular}{|c|c|}
\hline Scenario \# & Maximum wave height in St. Paul Harbor, $\mathbf{m}$ (ft) \\
\hline 1 & $0.5(1.6)$ \\
\hline 2 & $0.8(2.6)$ \\
\hline 3 & $0.6(2.0)$ \\
\hline 4 & $0.9(3.0)$ \\
\hline 5 & $1.7(5.6)$ \\
\hline 6 & $3.0(9.8)$ \\
\hline 7 & $2.5(8.2)$ \\
\hline 8 & $1.2(3.9)$ \\
\hline 9 & $0.9(3.0)$ \\
\hline 10 & $0.8(2.6)$ \\
\hline 11 & $0.8(2.6)$ \\
\hline
\end{tabular}

